\title{
The Debt Tax Shield in General Equilibrium
}

\author{
Fischer, Marcel; Jensen, Bjarne Astrup
}

Document Version

Accepted author manuscript

Published in:

Journal of Banking \& Finance

DOI:

10.1016/j.jbankfin.2018.12.014

Publication date:

2019

\section{License \\ CC BY-NC-ND}

Citation for published version (APA):

Fischer, M., \& Jensen, B. A. (2019). The Debt Tax Shield in General Equilibrium. Journal of Banking \& Finance, 100, 151-166. https://doi.org/10.1016/j.jbankfin.2018.12.014

Link to publication in CBS Research Portal

\section{General rights}

Copyright and moral rights for the publications made accessible in the public portal are retained by the authors and/or other copyright owners and it is a condition of accessing publications that users recognise and abide by the legal requirements associated with these rights.

Take down policy

If you believe that this document breaches copyright please contact us (research.lib@cbs.dk) providing details, and we will remove access to the work immediately and investigate your claim. 


\section{The Debt Tax Shield in General Equilibrium Marcel Fischer, Bjarne Astrup Jensen

\author{
Journal article (Accepted manuscript*)
}

\section{Please cite this article as:}

Fischer, M., \& Jensen, B. A. (2019). The Debt Tax Shield in General Equilibrium. Journal of Banking \& Finance, 100, 151-166. https://doi.org/10.1016/j.jbankfin.2018.12.014

DOI: https://doi.org/10.1016/j.jbankfin.2018.12.014

* This version of the article has been accepted for publication and undergone full peer review but has not been through the copyediting, typesetting, pagination and proofreading process, which may lead to differences between this version and the publisher's final version AKA Version of Record.

Uploaded to CBS Research Portal: August 2019

(C) 2019. This manuscript version is made available under the CC-BY-NC-ND 4.0 license

http://creativecommons.org/licenses/by-nc-nd/4.0/ 


\title{
The debt tax shield in general equilibrium
}

\author{
Marcel Fischer ${ }^{1}$ \\ University of Konstanz and Copenhagen Business School \\ Bjarne Astrup Jensen \\ Copenhagen Business School
}

\begin{abstract}
We study the general-equilibrium effects of the corporate debt tax shield in an endowment economy with a redistributive tax system that taxes firm profits and household income and redistributes tax revenues in an attempt to harmonize households' lifetime consumption opportunities. In general equilibrium, the debt tax shield not only affects corporate capital structure and valuation but also causes poorer households to consume more and save less at a younger age. Without the debt tax shield, the same welfare improvements for poorer households are achievable with significantly lower tax rates.
\end{abstract} JEL classification: G11, E21, H23, H31, H32

Keywords: debt tax shield, corporate leverage, general equilibrium, endowment economy, redistributive taxation

\section{Introduction}

Since the pioneering work of Modigliani and Miller (1958), understanding companies' capital structure decisions and their implications has grown to one of the most important areas of study in financial economics. Especially, the impact of the tax deductibility of companies' interest expenses, the corporate debt tax shield, has caught a large amount of attention. Despite all the progress that has been made in understanding the implications of corporate taxation and how the debt tax shield affects corporate capital structure, little is known about how the debt tax shield affects households' consumption-investment strategies.

\footnotetext{
Email addresses: mf.fi@cbs.dk (Marcel Fischer), ba.fi@cbs.dk (Bjarne Astrup Jensen)

${ }^{1}$ Corresponding author. University of Konstanz, Department of Economics, Chair of Finance, PO Box 147, Universitätsstr. 10, D-78457 Konstanz, Germany. 
Theoretical studies on the debt tax shield have focused on determining the value of the debt tax shield and optimal corporate leverage in partial equilibrium where taxes paid are treated as deadweight losses. To the best of our knowledge, this paper is the first to show that the debt tax shield is not only important for corporate valuation, but via the government budget constraint - also affects household's consumption-investment decisions. To document this effect, it is important to work in general equilibrium and to specify how the government uses its tax revenues, because government spending typically affects households' budget constraints. The investigation of these effects in an analytically solvable general-equilibrium model is the main contribution of our paper.

The debt tax shield has recently garnered renewed interest in both theoretical and empirical work. Empirical work, including MacKie-Mason (1990), Graham (1996, 1999), Gordon and Lee (2001), Hovakimian, Opler, and Sheridan (2001), Bell and Jenkinson (2002), Graham and Lucker (2006), Becker, Jacob, and Jacob (2013), Longstaff and Strebulaev (2014), Devereux, Maffini, and Xing (2015), Doidge and Dyck (2015), Faccio and Xu (2015), Heider and Ljungqvist (2015), Faulkender and Smith (2016), and Ljungqvist, Zhang, and Zuo (2017), documents that companies' capital structure decisions are significantly affected by taxes and the debt tax shield. Graham (2000), Kemsley and Nissim (2002), and vanBinsbergen, Graham, and Yang (2010) estimate that the value of the debt tax shield accounts for around $10 \%$ of firm values. Schepens (2016) argues that tax shields therefore can be an important policy tool for, e.g., bank regulators. DeAngelo and Roll (2015) and Graham, Leary, and Roberts (2015) document the evolution of leverage ratios over time, Korajczyk and Levy (2003) and Halling, Yu, and Zechner (2016) over the business cycle, and Fan, Titman, and Twite (2012) and Öztekin (2015) examine cross-country differences. None of these papers, however, investigates how the debt tax shield affects households' consumption-investment decisions. The absence of such empirical investigation may reflect the lack of industrialized countries that have not implemented the debt tax shield, which renders an empirical analysis difficult and a theoretical approach more appealing.

Given the current worldwide trend of lowering corporate tax rates, the debt tax shield is an important policy tool that can, e.g., be used to reduce the loss of corporate tax revenue due to lower statutory corporate tax rates. The investigation of the implications 
of such policies for corporate capital structure, valuation, and households' consumptioninvestment decisions are the focus of our work. Adding to this, the debt tax shield and the overall issue of discriminatory taxation between equity and debt has been on the political agenda for some time. It is the subject of analysis and discussion within the European Union, OECD and other international organizations. Different initiatives to reduce the discriminatory taxation have been proposed under various names like, e.g., ACE ("Allowance for Corporate Equity") and CBIT ("Comprehensive Business Income Tax"). Analyses of such potential policy initiatives are found in, e.g., Fatica, Hemmelgarn, and Nicodeme (2013), de Mooij and Devereux (2011), and Spengel, Schmidt, Heckemeyer, and Nicolay (2016). The recent ATA directive (European Commission, 2016) from the European Union, limiting the ability to deduct interest payments to $30 \%$ of EBITDA, constitutes an actual policy initiative.

Governments often spend huge amounts on welfare programs to reduce inequality and to improve the living standards of poorer households. For instance, the amount spent on income and social security by the U.S. government has increased rapidly in the past, amounting to more than USD 1.4 trillion or 7\% of the GDP in 2016, and it is expected to increase further. In European countries, this fraction tends to be even higher; the biggest European economies, France, Germany, and Italy, for instance, each spent more than $25 \%$ of their GDP on social transfers in 2016.

In this paper, we consider a Lucas tree economy with a representative firm. Households earn income from investing in risk-free assets and risky equity, entitling them to the dividends from the Lucas tree. The government taxes household income and firm profits and redistributes tax revenues in an attempt to reduce disparities in lifetime consumption opportunities among households that differ in their financial endowments. ${ }^{2}$ That is, poorer households receive more in transfers than they pay in taxes. Poorer households thus benefit from the redistribution mechanism by attaining consumption shares exceeding their initial share of the Lucas tree.

Even though at first glance, the debt tax shield may appear somewhat dissociated from redistribution of wealth among households, it has a first-order effect via the following

\footnotetext{
${ }^{2}$ Piketty and Saez (2003), Atkinson, Piketty, and Saez (2011), Alvaredo, Atkinson, Piketty, and Saez (2013), and others document growing inequality, which has led both researchers, such as Piketty (2014), but also Main Street, such as the Occupy Wall Street movement, to call for redistribution.
} 
mechanism: Whether the debt tax shield applies or not affects the corporate tax base and thus the government's tax revenues. The government's tax revenues, however, are instrumental for its ability to pay out transfer income, i.e., for the redistribution of wealth among households. In other words, via the government's budget constraint, the debt tax shield has a first-order effect on redistributions among households.

The endogenous response of corporate leverage to tax incentives is the key to understand the general equilibrium implications of the debt tax shield. If the tax burden on firm profits paid out to households as interest is lower than that paid out as dividend, there is a tax advantage to debt financing and an incentive for the firm to operate with leverage, otherwise the firm remains unlevered. Whether the tax burden on firm profits paid out to households as interest is lower than that paid out as dividend depends on the the relation between the different tax rates and whether the debt tax shield applies or not.

In partial equilibrium, where taxes paid to the government are deadweight losses, households' budget constraints are not affected by government spending and households' consumption shares are independent of whether the debt tax shield applies or not. In general equilibrium, the debt tax shield reduces the tax burden on interest income and thus overall tax revenues. This reduction in tax revenues has to be made up for by a reduction in government spending; i.e., a reduction in transfers paid out, or by an increase in tax rates. Keeping tax rates constant, our model predicts that the debt tax shield heavily affects households' consumption-investment strategies. Consequently, partial and general equilibrium models lead to different predictions about how the debt tax shield affects households' consumption shares and portfolio strategies. Hence, it is important to investigate the implications of the debt tax shield for household behavior in general equilibrium, where the effects of fiscal policy on households' budget constraints are accounted for.

Tax revenues depend on the evolution of the economy and are therefore subject to macroeconomic risk. Consequently, transfer income is subject to macroeconomic risk. Poorer households as net recipients of transfer income therefore reduce their exposures to equity. In addition, these households save less at a younger age given the higher future transfers. These effects are more pronounced when the debt tax shield does not apply. In 
line with what has been excessively documented in the literature in partial equilibrium, our model confirms that, also in general equilibrium, a debt tax shield implies incentives to increase corporate leverage and thereby increase the value of the firm, since a debt tax shield implies that a larger share of future output remains for equity holders. This is so despite the fact that in an endowment economy model the level and the dynamics of output from the Lucas tree is unaffected by the capital structure. ${ }^{3}$

Other papers working with a similar redistributive tax system are Sialm (2006), Fischer and Jensen (2015), and Pástor and Veronesi (2016, 2017). Sialm (2006) focuses on the impact of a stochastic consumption tax on corporate valuation. Fischer and Jensen (2015) explore the impact of household income taxation on optimal equity exposures when households differ by income. Pástor and Veronesi (2016) investigate how skill, risk aversion, and investment risk affect income inequality among households. Pástor and Veronesi (2017) investigate the implications of different political party's redistributional policies on households' voting behavior. This paper takes a different stand in this line of research by (1) accounting for corporate leverage and the debt tax shield, (2) by including the taxation of company profits, and (3) by allowing for different tax rates on interest and equity income.

Another paper that also investigates the implications of the corporate debt tax shield, but has a different focus than our work is Glover, Gomes, and Yaron (2015). Glover, Gomes, and Yaron (2015) investigate the impact of the debt tax shield on corporate leverage, corporate defaults, and credit spreads. However, their work is conducted in a general equilibrium framework in the sense that there is no government and hence, taxes paid are not accounted for. Their model predicts that removing an existing debt tax shield increases the corporate default frequency and leads to higher average credit spreads. Our work complements Glover, Gomes, and Yaron (2015) by investigating the generalequilibrium implications of the debt tax shield for households' consumption-investment decisions.

This paper contributes to what Fama (2011) calls one of the big open challenges in financial economics: understanding the implications of corporate taxation. Our work

\footnotetext{
${ }^{3}$ The property that the output process is unaffected by the choice of capital structure is one of the critical assumptions in the capital structure literature and the Modigliani-Miller propositions. See also Rubinstein (2003) and Giesecke and Goldberg (2004) for illuminating discussions.
} 
extends the literature in various dimensions. First, it shows that the debt tax shield not only affects corporate leverage and valuation, but also households' consumptioninvestment strategies. Without the debt tax shield, corporate profits are lower, implying lower consumption shares for richer households as the main shareholders. Simultaneously, without the debt tax shield, tax revenues are higher, which means that net transfer income for poorer households that receive more in transfers than they pay in taxes is higher. Consequently, their consumption shares of aggregate output increase. Second, the debt tax shield affects households' investment strategies. Without the debt tax shield, poorer households save less at a younger age to account for higher future transfer income. Third, when removing existing debt tax shields, governments could significantly reduce tax rates without reducing poorer households' welfare levels.

The paper proceeds as follows. Section 2 introduces our general-equilibrium model, while section 3 provides its solution in closed form. Next, in section 4, we illustrate the quantitative implications of the debt tax shield on the firm value and households' consumption-investment strategies. Section 5 concludes the paper.

\section{A general-equilibrium model with debt tax shield}

\subsection{The economy}

We consider an economy populated with $n$ households and a financial market in which three assets are traded. First, households can trade a locally risk-free, one-period bond paying a pretax return of $r_{t}$ from time $t$ to $t+1$. This asset comes in zero net supply. That is, if some households want to hold a long position in that asset, the market equilibrium has to bring about an interest rate that makes other households willing to issue such an asset. Second, households can invest in one-period corporate bonds issued by the representative firm (the Lucas tree) which makes up the production sector.

We adopt the Modigliani and Miller (1958) framework in which the representative firm cán only issue bonds up to a limit where there is no risk of bankruptcy. Hence, corporate bonds are perfect substitutes for the risk-free bond traded among households and therefore bear the same yield. ${ }^{4}$

\footnotetext{
${ }^{4}$ In section 3.1, we provide a formal criterion on corporate leverage ensuring this condition.
} 
Third, households can trade risky equity that entitles them to the firm's dividend payments in proportion to their equity shares. For simplicity and without loss of generality, we assume that the aggregate supply of equity is normalized to one unit.

The company's aggregate production or aggregate output at time $t, O_{t}$, is a perishable fruit from the Lucas tree (Lucas, 1978). In our endowment economy setting, aggregate production is exogenously given and can be affected by neither household saving nor by government policy. ${ }^{5}$ We assume that the gross growth of aggregate output from one period to the next is given by independent copies of a discrete random variable $G$, with $M$ possible equally likely realizations $G_{m}$, where $G_{1}>G_{2}>\ldots>G_{M} \cdot{ }^{6}$ Hence, aggregate output at the initial date $t=0$ can be normalized to $O_{0}=1$ without loss of generality.

\subsection{Household preferences}

Each household maximizes its present discounted expected utility from consumption subject to its intertemporal budget constraint. Hoúseholds have time-additive constant relative risk aversion utility functions with common risk aversion parameter $\gamma>0$ :

$$
U\left(C_{0, j}\right)+\sum_{t=1}^{N} \rho^{t} \mathbb{E}_{0}\left[U\left(C_{t, j}\right)\right], j=1,2, \ldots, n,
$$

where $\rho$ denotes the households' common time preference parameter and the utility from a consumption of $C$ is given by:

$$
U(C)= \begin{cases}\frac{C^{1-\gamma}}{1-\gamma} & \text { if } \gamma \neq 1 \\ \ln (C) & \text { if } \gamma=1\end{cases}
$$

Households differ by their initial financial endowments. For simplicity, we assume that households initially hold identical shares of equity and company debt, and denote household $j$ 's initial equity share by $\alpha_{0-, j}>0, j=1, \ldots, n$ with $\sum_{j=1}^{n} \alpha_{0-, j}=1$. There are initially no open positions in the risk-free bond traded among households. Hence,

\footnotetext{
${ }^{5}$ This is backed empirically by Grant, Koulovatianos, Michaelides, and Padula (2010), who only find a weak relationship between redistributive taxation and aggregate consumption.

${ }^{6}$ The assumption that the $M$ possible growth rates of the production process have equal probability is made to avoid an excessive use of notation. Our results readily generalize to the case with unequal probabilities.
} 
$\alpha_{0-, j}$ simultaneously determines household $j$ 's pre-tax share of output at time $t=0$ and its share of the aggregate initial endowment in the economy.

In this standard asset pricing and asset allocation model it is well known that households do not have any incentive to trade with each other nor issue bonds, and their consumption and equity shares correspond to their initial endowments. Essentially, all households are identical up to a scaling factor, and all households want to hold a position in the stock market corresponding to their initial endowment. Despite that financial markets are incomplete in the sense that a complete set of state-contingent claims cannot be constructed from the given stock and bond market, it is effectively complete in the sense that the conditions for an unconstrained Pareto optimal allocation can be obtained. Asset prices are determined by the use of a representative agent with the same utility function, and the risk neutral measure can be derived from the marginal utilities of the representative agent.

\subsection{The redistributive tax system}

We now introduce a government and a taxation and redistribution mechanism that implies heterogeneity among households, which leads to active trading in financial markets and also have asset pricing and asset allocation implications. Table 1 summarizes the notation and variables used in this paper.

In line with one of its central roles, we assume that the government seeks to reduce disparities in lifetime consumption opportunities among households. To that end, it imposes taxes on the company's profit at rate $\tau_{C}$, households' dividend and capital gains at rate $\tau_{E}$, and households' interest from bond holdings at rate $\tau_{B}$. The government implements a linear redistributive tax system where each household receives an identical share of tax revenues. That is, poorer households pay less in taxes than they receive in transfer income. These households are therefore net recipients of transfer income, whereas richer households are net contributors to the system. The linear redistributive tax system reduces the disparity among households by shrinking the initial consumption shares before tax towards a more equal distribution. In this way, the initial ranking of households with respect to their distribution of consumption shares remains unchanged by the redistribution mechanism. Such linear redistributive tax systems are commonly used in the public finance literature. Their use dates back to the work of Romer (1975) 
Table 1

Definition of variables

\begin{tabular}{ll} 
Variable & Description \\
\hline$\rho$ & The households' common utility discount factor \\
$\gamma$ & The households' common relative risk aversion coefficient \\
$\alpha_{0-, j}$ & Household $j$ 's initial endowment \\
$\alpha_{t, j}$ & Household $j$ 's share of aggregate investments in the production process at time $t$ \\
$\beta_{t, j}$ & Number of units of risk-free asset held by household $j$ from time $t$ to $t+1$ \\
$\delta_{t, j}$ & Number of units of corporate bonds held by household $j$ from time $t$ to $t+1$ \\
$\delta_{t}^{a}$ & Number of corporate bonds outstanding from time $t$ to $t+1$ \\
$L$ & Firm's leverage ratio \\
$C_{t, j}$ & Household $j$ 's consumption at time $t$ \\
$\tau_{E}$ & Tax rate applicable to household income from equity \\
$\tau_{B}$ & Tax rate applicable to household income from bonds \\
$\tau_{C}$ & Corporate tax rate \\
$\widehat{\tau}_{C}$ & Corporate tax rate applicable to a firm's interest payments \\
$R_{t}$ & Gross risk-free rate from time $t$ to $t+1$ \\
$O_{t}$ & Output from Lucas tree at time $t$ (exogenously given) \\
$\Omega_{t}$ & Taxable corporate income at time $t$ \\
$D_{t}$ & Dividend from Lucas tree at time $t$ \\
$P_{t}$ & Value of the firm's equity at time $t$ \\
$V_{t}$ & Value of the firm at time $t$ \\
$G_{t}$ & Gross growth factor of output $O$ \\
$\widetilde{R}_{t}$ & Gross risk-free rate after tax from time $t$ to $t+1$ for households \\
$\widehat{R}_{t}$ & Gross risk-free rate after tax from time $t$ to $t+1$ for firms \\
$W_{t, j}$ & Household $j$ 's wealth level at time $t$ before consumption \\
$n$ & Number of households in the economy \\
$N$ & Length of investment horizon in periods \\
\hline &
\end{tabular}

and Meltzer and Richard (1981) and has later been used, among others, in Alesina and Angeletos (2005), Sialm (2006), Fischer and Jensen (2015), and Pástor and Veronesi $(2016,2017){ }^{7}$

With homogeneity in households' endowments, all households would pay as much in taxes as they receive in transfers. Hence, the redistributive tax system would not affect their behavior. Similarly, as mentioned above, without the redistributive tax system we know that the households would neither trade with each other nor issue bonds, and their consumption and equity shares would correspond to their initial endowments. Heterogeneity in households' endowments combined with the linear redistribution mechanism causes households to trade with each other.

\footnotetext{
${ }^{7}$ In Fischer and Jensen (2015) the linear redistributive taxation system is the result of optimizing a government objective function.
} 
The linear redistribution mechanism simultaneously implies that the government neither builds up wealth nor debt. In our endowment economy, output is exogenously given. As a result, any government intervention can only result in a reallocation of consumption opportunities among households. Such reallocations, however, are already implemented through the redistributive tax system. There is no further scope for fiscal policy. Within the time horizon of our model, any government debt has to be settled by the households. ${ }^{8}$ Hence, households will never consider government debt as net wealth (Barro, 1974).

Given that the net supply of the risk-free asset traded among households is zero, tax revenues at time $t$ only depend on the company's dividend, $D_{t}$, the aggregate amount of company bonds outstanding, $\delta_{t}^{a}$, and the change in the value of the firm, $P_{t}-P_{t-1}$. The change in the value of the firm may be negative during a bust in the economy. However, we want the net value of aggregate production, which is the dividend corrected for the value adjustment of the capital stock, to be positive. This ensures that the capital tax base from ownership in the Lucas tree is non-negative and that the company is solvent at the horizon date. Hence, we require $P_{t}+D_{t}-P_{t-1} \geq 0$ for all $t$, and section 3.1 provides a formal restriction on the degree of corporate leveraging that ensures this condition. ${ }^{9}$

\subsection{The debt tax shield}

Whether a government implements a debt tax shield or not should, among others, be heavily driven by two normative considerations. On the one hand, not having a debt tax shield may be considered desirable as it increases the tax base, thus leads to higher tax revenues, and ultimately to a lower degree of inequality among the households' lifetime consumption opportunities. On the other hand, not having a debt tax shield may be considered undesirable as it leads to a double-taxation of interest at both the company level and the level of the final recipient of the interest payment.

Whether the debt tax shield applies to a company's interest expenses or not has important implications for its optimal capital structure, because the debt tax shield reduces the after-tax cost of debt. The debt tax shield also has a first-order effect on the

\footnotetext{
${ }^{8}$ We explicitly disregard the opportunity that the government can embark on a Ponzi scheme and ignore its long-run budget constraint.

${ }^{9}$ Whereas the restriction $P_{t}+D_{t}-P_{t-1} \geq 0$ has the desirable feature of guaranteeing a net value of production and a non-negative tax basis, technically, it is not a requirement for our analysis. Our model has the same closed-form solution without this restriction.
} 
dividend, $D_{t}$, paid out to the company's shareholders:

$$
D_{t}=\left(1-\tau_{C}\right) O_{t}-\widehat{R}_{t-1} \delta_{t-1}^{a}+\delta_{t}^{a}
$$

where

$$
\widehat{R}_{t-1}=1+r_{t-1}\left(1-\widehat{\tau}_{C}\right)
$$

is the company's gross after-tax risk-free rate from time $t-1$ to time $t$, after accounting for whether the debt tax shield exists or not, and

$$
\widehat{\tau}_{C}= \begin{cases}\tau_{C} & \text { with debt tax shield } \\ 0 & \text { without debt tax shield }\end{cases}
$$

is the tax rate on interest expenses at the corporate level ${ }^{10}$ With the debt tax shield, the company faces lower debt servicing costs, implying a higher dividend paid out to its shareholders. The debt tax shield also reduces the tax basis for corporate profits and thus the government's tax revenues. With the debt tax shield, the government's net tax revenues from taxing interest on the household level minus the tax credit granted on the corporate level are non-negative if $\tau_{B} \geq \tau_{C}$, which we therefore assume throughout.

\subsection{Determination of corporate levering}

An endogenous determination of corporate leverage is important for understanding the general equilibrium implications of the corporate debt tax shield. In our paper we allow the representative firm to endogenously choose its optimal capital structure within the Modigliani and Miller (1958) framework, where there is no risk of bankruptcy. ${ }^{11}$

We follow one of the standard assumptions in the literature and take for granted that the representative firm chooses a constant leverage ratio, $L=\delta_{t}^{a} / P_{t}$. The use of a constant leverage ratio is usually referred to as the Miles-Ezzell assumption (Miles and

\footnotetext{
${ }^{10} \mathrm{We}$ do not explicitly regard the case, where interest expenses are deductible, but the tax compensation for deductions is lower than the tax paid on corporate profits $\left(0<\widehat{\tau}_{C}<\tau_{C}\right)$. Our model can be readily applied to these cases.

${ }^{11}$ Allowing the representative firm to default would imply that the corporate sector as a whole is defaulting. Allowing for individual corporate defaults in a general equilibrium setting requires a more elaborate corporate sector with many and different firms with different capital structures. We are not aware that analyses of this kind exist in the literature so far, and it is outside the scope of the present paper.
} 
Ezzell, 1980). It is used in the work of Cooper and Nyborg (2006, 2008), among others, and it is consistent with our constant returns to scale assumption for the growth process of aggregate output.

The total tax burden on equity is independent of whether the debt tax shield applies or not. It is given by the corporate tax rate $\tau_{C}$ and the tax rate on equity income, $\tau_{E}$, as $\tau_{C}+\tau_{E}\left(1-\tau_{C}\right)$. The total tax burden on interest income, however, depends on whether the debt tax shield applies or not. Without the debt tax shield, the total tax burden on interest income is $\tau_{C}+\tau_{B}\left(1-\tau_{C}\right)$; that is, the firm operates with leverage if $\tau_{B}<\tau_{E}$ in that case. With the debt tax shield, the total tax burden on interest income is just $\tau_{B}$. Hence, the firm chooses a positive leverage if $\tau_{B}<\tau_{C}+\tau_{E}\left(1-\tau_{C}\right)$, equivalent to $1-\tau_{B}>\left(1-\tau_{C}\right)\left(1-\tau_{E}\right)$. That is, if the after tax value of a unit payout from the firm as interest payment, $1-\tau_{B}$, is larger than the after tax value of a unit payout from the firm as dividends, $\left(1-\tau_{C}\right)\left(1-\tau_{E}\right)$. In particular, for $\tau_{E}<\tau_{B} \leq \tau_{E}+\tau_{C}\left(1-\tau_{E}\right)$, the firm operates with leverage when the debt tax shield applies and without when it does not apply. More specifically, later in Theorem 1, item 4, we show that when it is optimal for the firm to operate with corporate leverage, it is optimal for the firm to choose the maximum possible degree of leverage. In subsection 4.6, we exogenously vary the degree of corporate leverage to explore the impact of other degrees of leverage.

\subsection{The households' optimization problem}

A household can invest in the right to future consumption output $C_{t}$ at time $t$ in three ways. First, it can invest in equity, directly receiving its proportional share, $\alpha_{t-1, j}$, of the dividend $D_{t}$ from the production process. Second, the household can invest an amount, $\delta_{t-1, j}$, in corporate bonds, for which the repayment at time $t, \delta_{t-1, j} R_{t-1}$, is unrelated to the outcome of the production process. Third, households have the opportunity to issue or invest in risk-free bonds that are traded among them. The amount invested in such bonds from time $t-1$ to $t$ by household $j$ is denoted $\beta_{t-1, j}$ and provides the household with a payment of $\beta_{t-1, j} R_{t-1}$ at time $t$.

Household $j$ 's wealth after accounting for tax effects consists of five components. First, the household owns its share of the Lucas tree, $\alpha_{t-1, j} P_{t}$. Second, the household receives its share of the dividend passed from the company to its shareholders. After accounting 
for the taxation of the dividend, this leaves the household with an income of

$$
\alpha_{t-1, j}\left(1-\tau_{E}\right) D_{t}
$$

Third, the household receives income from its holdings of the risk-free asset and company bonds of

$$
\left(\beta_{t-1, j}+\delta_{t-1, j}\right) \widetilde{R}_{t-1}
$$

where

$$
\widetilde{R}_{t-1}=1+r_{t-1}\left(1-\tau_{B}\right)
$$

is the household's gross risk-free rate from time $t-1$ to $t$ after aceounting for the taxation of interest payments on the household level. Fourth, the household has to pay capital gain taxes on the appreciation of the value of its equity holdings:

$$
\alpha_{t-1, j} \tau_{E}\left(P_{t}-P_{t-1}\right)
$$

Finally, the household receives transfer income. The household's transfer income depends on the amount of taxes that tax authorities collect, which in turn consists of four components. First, the government generates a tax revenue of $\tau_{E} D_{t}$ by taxing households' dividends. Second, $\tau_{B} r_{t-1} \delta_{t-1}^{a}$ is the tax revenue from taxing households' interest income. Third, taxing households' capital gains gives a tax revenue of $\tau_{E}\left(P_{t}-P_{t-1}\right)$. Finally, the government taxes the company's profit, $\Omega_{t}$, at the corporate tax rate $\tau_{C}$ :

$$
\Omega_{t}= \begin{cases}O_{t}-r_{t-1} \delta_{t-1}^{a} & \text { with debt tax shield } \\ O_{t} & \text { without debt tax shield }\end{cases}
$$

Total tax revenues are thus given by

$$
\tau_{E} D_{t}+\tau_{C} \Omega_{t}+\tau_{B} r_{t-1} \delta_{t-1}^{a}+\tau_{E}\left(P_{t}-P_{t-1}\right)=\tau_{E}\left(P_{t}+D_{t}-P_{t-1}\right)+\tau_{C} \Omega_{t}+\tau_{B} r_{t-1} \delta_{t-1}^{a},
$$

of which each household receives its share $1 / n$.

A removal of an existing debt tax shield, ceteris paribus, always leads to corporate profits of a levered firm being taxed more heavily irrespective of whether the corporation 
decides to keep operating with corporate leverage after the removal of the debt tax shield or not. Similar to, for example, an increase in the tax rate on equity income, $\tau_{E}$, a removal of the debt tax shield thus results in an additional transfer of wealth. ${ }^{12}$

Equations (10) and (11) show that total tax revenues contain a risky component, $\tau_{C} O_{t}+\tau_{E}\left(P_{t}+D_{t}-P_{t-1}\right)$, which depends on the evolution of the economy and, when the firm operates with leverage, a risk-free part: $\left(\tau_{B}-\tau_{C}\right) r_{t-1} \delta_{t-1}^{a}$ with the debt tax shield, and $\tau_{B} r_{t-1} \delta_{t-1}^{a}$ without. That is, the redistributive tax system not only redistributes wealth from richer to poorer households, but simultaneously transfers macroeconomic risk, which households have to take into account when making their consumptioninvestment decisions.

Equations (10) and (11) reveal that the level of tax revenues is affected through two channels on whether the debt tax shield applies or not. First, as already outlined in section 2.5, the debt tax shield affects whether the corporation levers up or not. Second, conditional on corporate levering, the debt tax shield determines the level of risk-free tax revenues from taxation of interest payments.

Household $j$ 's wealth before trading and consumption at time $t$ is then given by:

$$
\begin{aligned}
W_{t, j}= & \alpha_{t-1, j} P_{t}+\alpha_{t-1, j}\left(1-\tau_{E}\right) D_{t}+\left(\beta_{t-1, j}+\delta_{t-1, j}\right) \widetilde{R}_{t-1}-\alpha_{t-1, j} \tau_{E}\left(P_{t}-P_{t-1}\right)+ \\
& \frac{1}{n}\left(\tau_{E}\left(P_{t}+D_{t}-P_{t-1}\right)+\tau_{C} \Omega_{t}+\tau_{B} r_{t-1} \delta_{t-1}^{a}\right) .
\end{aligned}
$$

Household $j$ 's optimization problem then becomes:

$$
\begin{aligned}
& \left\{\left\{C_{t, j}\right\}_{t=0}^{t=0},\left\{\alpha_{t, j}, \beta_{t, j}, \delta_{t, j}\right\}_{t=0}^{t=N-1}\right\} \\
& \text { s.t. }{ }^{\prime-\gamma} C_{0, j}^{1-\gamma}+\sum_{t=1}^{N} \rho^{t} \mathbb{E}_{0}\left[\frac{1}{1-\gamma} C_{t, j}^{1-\gamma}\right] \\
& C_{t, j}=W_{t, j}-\alpha_{t, j} P_{t}-\left(\beta_{t, j}+\delta_{t, j}\right) \\
& \alpha_{N, j}=\beta_{N, j}=\delta_{N, j}=0 .
\end{aligned}
$$

Having introduced the household's optimization problem, we next turn to a derivation of the general equilibrium implications of the debt tax shield and corporate debt for asset

\footnotetext{
${ }^{12}$ In contrast to an increased tax rate on equity income, however, the removal of the debt tax shield does not alter the amount of macroeconomic risk transferred between households, implying that households should react differently to a reduction in $\tau_{E}$ and a removal of the debt tax shield.
} 
prices and households' consumption-investment strategies.

\section{General-equilibrium effects of the debt tax shield}

\subsection{Asset pricing}

We begin the presentation of the general-equilibrium solution of the optimization problem stated in Equations (13) through (15) by summarizing results on corporate valuation and the risk-free rate. To ensure a finite firm value even when the length of the investment horizon, $N$, goes to infinity, we require the firm's discount factor to exceed the expected gross growth rate of the real investment under the risk-neutral measure. In order to guarantee this, we require that

$$
\rho \mathbb{E}\left[G^{1-\gamma}\right]<\min \left(1, G_{M}\right)
$$

A sufficient (but not necessary) condition for this inequality to hold is $\rho<1, \gamma \geq 1$, and $G_{M} \geq 1$. Furthermore, we impose the following exogenous constraint to the degree of leverage for the representative firm:

$$
L \leq \frac{1}{\widehat{R}} \frac{G_{M}\left(1+\frac{\widetilde{r}}{1-\tau_{E}}\right)-\bar{G}}{\bar{G}-G_{M}}
$$

where $\bar{G} \equiv \mathbb{E}^{Q}[G]$ and $\mathbb{E}^{Q}$ denotes the expectation operator under the risk-neutral measure. In the proof of Theorem 1, we show that this constraint on corporate leverage ensures a non-negative tax base from taxing company income. It holds for $L=0$ but imposes a constraint on the maximum degree of corporate leverage relative to the volatility of the growth process. Similarly, we show in the proof of Theorem 1 that for $\bar{G}>1$,

$$
L \leq \frac{1+\frac{\widetilde{r}}{1-\tau_{E}}-\bar{G}}{\widehat{R}(\bar{G}-1)}
$$

is a sufficient (but not necessary) condition for the dividend paid out to shareholders being non-negative. For $\bar{G} \leq 1$, the non-negativity of the dividend is trivially fulfilled. We report our results in Theorem 1 parametrically in the degree of corporate leverage to 
facilitate the interpretation of some of our results: ${ }^{13}$

Theorem 1. For the risk-free rate and corporate valuation, it holds that:

1. The gross risk-free rate after taxation on household level is constant and given by

$$
\widetilde{R} \equiv 1+\widetilde{r}=1+r\left(1-\tau_{B}\right)=\frac{1}{\rho \mathbb{E}\left[G^{-\gamma}\right]}=\frac{\bar{G}}{\rho \mathbb{E}\left[G^{1-\gamma}\right]}
$$

Given the parameter restriction in Equation (16), the interest rates before and after taxation on household level are positive: $r>0$ and $\widetilde{r}>0$.

2. The value of the firm's equity, $P_{t}$, is given by:

$$
P_{t}=\frac{1}{K} \mathbb{E}_{t}^{Q}\left[P_{t+1}\right]+\frac{1}{K(1+L)}\left(1-\tau_{C}\right) \mathbb{E}_{t}^{Q}\left[O_{t+1}\right], \quad P_{N}=0
$$

where

$$
K=1+\frac{1}{1+L} \frac{\widetilde{r}}{1-\tau_{E}}+\frac{L}{1+L} \widehat{r}
$$

and $K>\bar{G}$. The value of the firm's equity can be expressed explicitly as

$$
P_{t}=\frac{1}{1+L} \frac{1-(\bar{G} / K)^{N-t}}{K-\bar{G}} \bar{G}\left(1-\tau_{C}\right) O_{t}=\frac{1}{1+L} \sum_{j=1}^{N-t}\left(\frac{\bar{G}}{K}\right)^{j}\left(1-\tau_{C}\right) O_{t}
$$

For $t<N, P_{t}$ is lower without the debt tax shield for a levered firm. For $N \rightarrow \infty$, the value of the firm's equity from Equation (22) takes on the form:

$$
P_{t}=\frac{1}{1+L} \frac{\bar{G}\left(1-\tau_{C}\right)}{K-\bar{G}} O_{t}
$$

3. The total firm value, $V_{t}$, consists of the value of the firm's equity, $P_{t}$, and the value of debt, $\delta_{t}^{a}$. It is given by

$$
V_{t}=P_{t}+\delta_{t}^{a}=P_{t}(1+L)=\frac{1-(\bar{G} / K)^{N-t}}{K-\bar{G}} \bar{G}\left(1-\tau_{C}\right) O_{t}
$$

The firm-value-to-output ratio, $V O_{t}=\frac{P_{t}+\delta_{t}^{a}}{O_{t}}$, is time-dependent, but state-independent at any given point in time. For a levered firm, the total firm value and the

\footnotetext{
${ }^{13}$ In our numerical examples in section 4 , we assume that corporate leverage is determined endogenously as the maximum degree of leverage allowed, consistent with an objective of maximizing firm value.
} 
firm-value-to-output ratio are lower without the debt tax shield. For $N \rightarrow \infty$, the total firm value from Equation (24) converges to

$$
V_{t}=P_{t}+\delta_{t}^{a}=\frac{\bar{G}\left(1-\tau_{C}\right)}{K-\bar{G}} O_{t}
$$

4. Whenever there is a tax advantage to using debt, the total firm value is increasing in the degree of leverage L. In this case it is therefore optimal for the firm to choose the maximum degree of corporate leverage that fulfills the solvency constraint from Equation (17). Furthermore, the incentive to lever up, interpreted as the relative increase in the total firm value, $V_{t}$, as a result of an increase in $L$, is increasing in the corporate tax rate $\tau_{C}$.

Proof A detailed proof of all items in Theorem 1 can be found in the Online Appendix available at https://papers.ssrn. com/sol3/papers.cfm?abstract_id=3312646.

Theorem 1 shows that corporate debt and the debt tax shield affect the pricing of the risk-free and the risky asset differently. According to item 1, the existence of corporate debt and the debt tax shield does not affect the risk-free rate. Equation (19) reveals that the well-known formula for the risk-free rate of interest - adjusted for the taxation of interest on household level - applies. ${ }^{14}$

In line with what has been excessively documented in the literature on partial equilibrium, Theorem 1, item 2, confirms that the debt tax shield also affects corporate valuation in general equilibrium. The company's interest rate after taxes, $\widehat{R}$, is higher without the debt tax shield. Hence, the discounting factor $K$ increases, in turn resulting in a decrease in the value of the firm's equity, $P_{t}$. When interest expenses are not tax deductible on the corporate level, the tax burden of a levered firm increases. Consequently, the share of output that goes to equity holders decreases along with the value of the firm's equity.

The discount factor $K$ from Equation (21) shows that the interest rate used for discounting the future price of equity and firm output takes a form similar to the weighted average cost of capital (WACC). WACC is typically applied under the physical measure, but in our setting, with risk-averse households, the WACC formula applies under the risk-neutral measure. ${ }^{15}$ Under this measure, the households' required rate of return on

\footnotetext{
${ }^{14}$ See, e.g., Rubinstein (1974), section 4 (Theorem on Valuation), or Rubinstein (1976), Theorem 4.

${ }^{15}$ There is a debate in the corporate valuation literature about whether risk adjustments should be
} 
equity income after taxes corresponds to the risk-free rate after taxes. With a tax rate on equity income of $\tau_{E}$, the rate of return before taxes has to be $\frac{\widetilde{r}}{1-\tau_{E}}$ to provide households with a rate of return of $\widetilde{r}$ after taxes. The firm's cost of debt after corporate taxes is $\widehat{r}$. Equation (21) thus shows that the firm's cost of capital is a weighted average of its cost of equity and debt with weights given by their respective fractions of the firm's capital structure.

If there is a tax advantage from using corporate debt, the total firm value and the firmvalue-to-output ratio increase in the firm's leverage ratio. Furthermore, from Theorem 1 , item 4 , this incentive is increasing in the corporate tax rate $\tau_{C}$. In the case with tax neutrality between equity and debt financing, i.e., when the Miller (1977) conditions hold with $\frac{\widetilde{r}}{1-\tau_{E}}=\widehat{r}$ and $K=\widehat{R}$, leverage has no effect on corporate valuation. Despite the fact that households are taxed on their income, the corresponding tax rates, $\tau_{E}$ and $\tau_{B}$, are irrelevant for corporate valuation in this case; the corporate tax rate is the only tax rate that matters. In other words, even with tax neutrality between equity and debt financing, where $K=\widehat{R}$, the debt tax shield has an impact on corporate valuation by affecting $\widehat{R}$.

In the more commonly studied framework, also referred to as the "classical system", it holds that $\tau_{C}>0$ and $\tau_{B}=\tau_{E}$. Dividend income is then subject to full double taxation, and the degree of leverage matters for corporate valuation due the tax-favored treatment of debt financing. However, the tax rates at the household level do not enter the discount factor $K$ :

$$
K=1+r\left(1-\frac{L}{1+L} \tau_{C}\right)=1+\frac{1}{1+L} r+\frac{L}{1+L} r\left(1-\tau_{C}\right)
$$

Except for the fact that we apply the risk-neutral measure instead of the physical measure, this corresponds to the usual WACC formula found in practically any corporate finance textbook. ${ }^{16}$

implemented by using the traditional WACC (risk adjustment "in the denominator") or by subtracting a risk premium directly in the expected future payments (risk adjustment "in the numerator"). We refer to Christensen and Feltham (2009) and the references therein for a more elaborate discussion.

${ }^{16} \mathrm{~A}$ thorough discussion in a more traditional corporate finance context is found in, e.g., Berk and DeMarzo (2013), chapter 15 ("Debt and Taxes"), and in section 18.8 ("Advanced Topics in Capital Budgeting"). 


\subsection{Leverage and corporate valuation}

To investigate the relationship between corporate leverage and the value of the firm's equity in more detail, we distinguish between two cases. First, without the debt tax shield, there is typically no tax advantage of debt, because in real-world tax legislation, it usually holds that $\tau_{B} \geq \tau_{E}$. Hence, the value of the firm's equity should decrease as the firm's leverage ratio increases due to the substitution of equity with debt. Second, with the debt tax shield, corporate interest expenses become tax deductible, thus allowing for a tax advantage of debt if $1-\tau_{B}>\left(1-\tau_{E}\right)\left(1-\tau_{C}\right)$. In that situation, higher corporate leverage can increase the value of the firm's equity, because it decreases the firm's cost of capital, thus implying a positive present value for the firm.

In contrast to the value of the firm's equity, $P_{t}$, a change in corporate leverage does not cause a substitution effect in the total firm value, $V_{t}$. For the total firm value, higher corporate leverage only results in a wealth effect. An increase in the corporate tax rate thus has two opposing effects on the valuation of the firm when there is a tax advantage to debt. On the one hand, the lower share of output falling to equity holders suggests a decrease in the firm value. On the other hand, the present value of the tax advantage increases, thus pointing towards an increase in firm value. Which of the two effects dominates depends on the exact parameter constellation and is investigated in more detail in our numerical examples in section 4.3.

In general, the total firm-value-to-output ratio, $V O_{t}$, depends on corporate leverage and the corporate tax rate, but is state-independent at any point in time. This is so, because the growth process of output is i.i.d., rendering the total firm value a constant multiple of output. When the length of the investment horizon, $N$, goes to infinity, the firm-value-to-output ratio is given by

$$
V O=\frac{\bar{G}\left(1-\tau_{C}\right)}{K-\bar{G}}
$$

which is a variant of the classical Gordon growth formula (Gordon and Shapiro, 1956; Gordon, 1959). The only term in Equation (27) that changes with corporate leverage is the firm's discount factor $K$.

To illustrate how corporate leverage affects the firm value under these more general conditions, we compare the firm-value-to-output ratio from Equation (27) in settings with 
and without corporate leverage. When $K_{U}$ denotes the value of $K$ for an unlevered firm and $K_{L}$ its counterpart for a levered firm, the value of a debt tax shield is given by

$$
\begin{aligned}
& \frac{\bar{G}\left(1-\tau_{C}\right)}{K_{L}-\bar{G}}-\frac{\bar{G}\left(1-\tau_{C}\right)}{K_{U}-\bar{G}}=\bar{G}\left(1-\tau_{C}\right) \frac{K_{U}-K_{L}}{\left(K_{L}-\bar{G}\right)\left(K_{U}-\bar{G}\right)}= \\
& \frac{\bar{G}\left(1-\tau_{C}\right)}{K_{L}-\bar{G}} \frac{L}{1+L} r\left(\frac{\frac{1-\tau_{B}}{1-\tau_{E}}-\left(1-\tau_{C}\right)}{K_{U}-\bar{G}}\right) .
\end{aligned}
$$

For a levered firm it is positive when there is a tax advantage of using corporate debt. In the classical system with identical tax rates on equity returns and interest payments on the household level $\left(\tau_{B}=\tau_{E}\right)$, Equation (28) simplifies to

$$
\frac{\bar{G}\left(1-\tau_{C}\right)}{K_{L}-\bar{G}} \frac{L}{1+L} \frac{r \tau_{C}}{K_{U}-\bar{G}} .
$$

Equation (29) corresponds to Equation (10) in Cooper and Nyborg (2006), except for the fact that due to the households' assumed risk aversion, our formula is under the risk-neutral and not the physical measure.

Overall, our results in this section show that the risk-free rate is unaffected by the corporate tax rate, corporate leverage, and the debt tax shield. The value of the firm's equity as well as the total firm value, however, are affected by the corporate tax rate, corporate leverage, and the debt tax shield. This is so despite the fact that aggregate consumption is exogenously given and that all taxes are returned to the agents via the transfers.

\subsection{Consumption-investment policies}

Having presented closed-form solutions for the valuation of the firm and the risk-free rate as well as the impact of leverage on corporate valuation in section 3.2, we next show how corporate leverage and the debt tax shield affect households' consumption and investment strategies in general equilibrium. Our key findings are summarized in Theorem 2:

Theorem 2. The allocation of macroeconomic risk is in accordance with a linear sharing rule relative to the distribution of wealth after taxes. For household $j$ 's consumption and investment policies, it holds that: 
1. The position in the risk-free asset from time $t-1$ to $t$ is given by

$$
\begin{aligned}
& \beta_{t-1, j}+\delta_{t-1, j}=\frac{1}{\widetilde{R}}\left(\frac{1}{n}-\alpha_{t-1, j}\right) \tau_{E} P_{t-1}+ \\
& L P_{t-1} \frac{1}{\widetilde{R}}\left(\left(\alpha_{t-1, j}\left(1-\tau_{E}\right)+\frac{\tau_{E}}{n}\right) \widehat{R}+\frac{r}{n}\left[\widehat{\tau}_{C}-\tau_{B}\right]\right) .
\end{aligned}
$$

For $N \rightarrow \infty$, the position in the risk-free asset is proportional to output with a constant proportionality factor given by:

$$
\begin{aligned}
& \frac{\beta_{t-1, j}+\delta_{t-1, j}}{O_{t-1}}=V O \frac{1}{\widetilde{R}}\left[\frac{1}{1+L}\left(\frac{1}{n}-\alpha_{j}\right) \tau_{E}+\right. \\
& \left.\frac{L}{1+L}\left(\left(\alpha_{j}\left(1-\tau_{E}\right)+\frac{\tau_{E}}{n}\right) \widehat{R}+\frac{r}{n}\left[\widehat{\tau}_{C}-\tau_{B}\right]\right)\right]
\end{aligned}
$$

where VO is the limiting value of the value-to-output ratio from Equation (27).

2. The equity share, $\alpha_{t, j}$, is given by

$$
\alpha_{t, j}=\frac{1}{n}+\left[\prod_{i=1}^{t} X_{i}\right]\left(\alpha_{0, j}-\frac{1}{n}\right), \quad t=1, \ldots, N-1
$$

where

$$
X_{i}=\frac{1+\frac{V O_{i}}{1-\tau_{C}}}{\prod_{k=i+1}^{N-1} X_{k}+\frac{K}{\widetilde{R}} \frac{V O_{i}}{1-\tau_{C}}}<1
$$

The deviation from an equal distribution of equity holdings diminishes over time. It diminishes at a faster rate without the debt tax shield; i.e., $\prod_{i=1}^{t} X_{i}$ is smaller without the debt tax shield.

At time $t=0$, it holds that

$$
\alpha_{0, j}=\frac{1}{n}+\left(\alpha_{0-, j}-\frac{1}{n}\right) \frac{1+\frac{V O_{0}}{1-\tau_{C}}}{\prod_{k=1}^{N-1} X_{k}+\frac{K}{\widetilde{R}} \frac{V O_{0}}{\left(1-\tau_{C}\right)}} \frac{1}{\left(1-\tau_{E}\right)} .
$$

The initial deviation from equal equity holdings is enlarged relative to the households' initial endowments; i.e., $\left|\alpha_{0, j}-\frac{1}{n}\right|>\left|\alpha_{0-, j}-\frac{1}{n}\right|$. For $N \rightarrow \infty$, the equity share is a constant and given by:

$$
\alpha_{j}=\frac{1}{n}+\left(\alpha_{0-, j}-\frac{1}{n}\right) \frac{1}{1-\tau_{E}} .
$$


3. The consumption policy is given by a constant share of aggregate output:

$$
\frac{C_{t, j}}{O_{t}}=\left(\alpha_{N-1, j}-\frac{1}{n}\right)\left(1-\tau_{E}\right)\left(1-\tau_{C}\right)+\frac{1}{n} .
$$

Consumption shares vary less among households without the debt tax shield. For $N \rightarrow \infty$, the consumption policy is given by a constant share of aggregate output:

$$
\frac{C_{t, j}}{O_{t}}=\frac{1}{n}+\widetilde{\alpha}_{0-, j}\left[1-\tau_{C}-V O\left(\frac{K}{\widetilde{R}}-1\right)\right] .
$$

Proof A detailed proof of all items in Theorem 2 can be found in the Online Appendix available at https://papers.ssrn.com/sol3/papers.cfm?abstract_id=3312646.

Our results in Theorem 2 show that corporate debt and the debt/tax shield not only affect corporate valuation but also households' consumption-investment strategies. Our households are risk averse and have identical degrees of risk aversion. They therefore strive for a linear sharing rule with a time- and state-independent share of aggregate household consumption and allocate macroeconomic pisk accordingly.

Households are exposed to macroeconomic risk through two channels. They are directly exposed to it by holding equity, and they are indirectly exposed to it via their transfer income. The level of transfer income depends on tax revenues, which in turn depend on the evolution of the economy. Hence, the redistributive tax system not only redistributes tax revenues but also macroeconomic risk.

In the absence of corporate levering, i.e., for $L=0$, the bond position in Equation (30) is positive for poorer households with below-average equity investments. The bond position is proportional to $\tau_{E}$ times the total firm value $P_{t-1}$. That is, the imputed macroeconomic risk resulting from the redistributive tax system causes poorer households to decrease their equity holdings and to establish a long position in the risk-free asset instead. This is the first term in Equation (30).

With corporate levering $(L>0)$, additional effects affect the bond position. All of them are proportional to the amount of corporate debt $\delta_{t-1}^{a}=L P_{t-1}$. When the firm operates with corporate leverage, any equity holder incurs an implicit short position in corporate bonds. After accounting for the taxation of firm profits on household level and the resulting redistributions, the implicit short position has a present value 
of $(\widehat{R} / \widetilde{R})\left(\alpha_{t-1, j}\left(1-\tau_{E}\right)+\tau_{E} / n\right)$ per unit of corporate debt. As Equation (30) shows, household $j$ holds a corresponding long position in its portfolio in order to undo this short position. The term $(r / n)\left(\widehat{\tau}_{C}-\tau_{B}\right)$ corrects for the difference between the tax treatment of interest income at the firm and household levels and the implied effect on redistribution. Simultaneously, this hedging demand insures that aggregate demand for corporate bonds meets aggregate supply.

When the tax system is neutral and the Miller 1977 conditions hold, $1-\tau_{B}=$ $\left(1-\widehat{\tau}_{C}\right)\left(1-\tau_{E}\right)$, corporate levering does not affect tax revenues and transfers paid. The bond position becomes:

$$
\beta_{t, j}+\delta_{t, j}=\frac{1}{\widetilde{R}} V_{t}\left(\frac{1}{n}-\alpha_{t, j}\right) \tau_{E}+L P_{t} \alpha_{t, j}
$$

In this case, the value of the firm, $V_{t}$, as well as the tax revenue is independent of corporate levering. The first term therefore has the same form as it would have for an all equity financed firm. The debt-related second term is proportional to the household's equity position. It neutralizes the equity holder's implicit short position in the risk-free asset.

Consumption shares vary less among households without the debt tax shield (Theorem 2, item 3). Tax revenues and thus transfers are higher without the debt tax shield. Without the debt tax shield, the corporate tax base is enlarged by the interest expenses that, in the presence of the debt tax shield, would be tax-exempt. Unlike investments into the firm's equity, the interest rate is not subject to macroeconomic risk in our model. In other words, the additional tax revenues from removing an existing debt tax shield are not subject to macroeconomic risk. Therefore removing an existing debt tax shield leads to an additional transfer of wealth to poorer households, whereas the level of imputed macroeconomic risk is not affected. Hence, without the debt tax shield, poorer households attain higher consumption shares.

Item 2 in Theorem 2 shows that whenever there is a tax advantage of using debt, the initial deviation from equal equity holdings is enlarged. That is, poorer households reduce their equity holdings from time $t=0$ to $t=1, \alpha_{0, j}$, below their initial endowment, $\alpha_{0-, j}$, whereas richer household increase their initial exposures beyond their initial endowments. However, deviations from an equal distribution of equity holdings diminish over time. That is, the equity holdings of poorer household increase over time, whereas those of 
richer households decrease. This pattern reflects the redistribution of wealth from richer to poorer households. The amount of wealth redistributed is higher without the debt tax shield. Consequently, equity shares converge towards an equal distribution at a faster rate without the debt tax shield.

The impact of the debt tax shield on a household's equity exposure is mainly driven through two channels. First, there is a substitution effect. More specifically, without the debt tax shield, poorer households receive a higher amount of transfer income that is not subject to macroeconomic risk. ${ }^{17}$ Consequently, these households substitute bonds with equity holdings. Second, there is a wealth effect. Without the debt tax shield, more wealth is transferred between households. Taking the present value of future transfers into account, poorer households can thus finance a higher consumption share by decreasing their investments. This decrease in investments affects both their bond and equity holdings. That is, a household's exposure to equity is driven by two counteracting effects.

When the remaining investment horizon is long, the wealth effect is strong, implying lower equity exposures for poorer households without the debt tax shield. When the remaining investment horizon is very short, the importance of the substitution effect grows, and equity exposures for poorer households may be higher without the debt tax shield.

To illustrate, consider household $j$ 's equity exposure at time $t=0$ from Equation (34), which can be rewritten as:

$$
\left(\alpha_{0, j}-\frac{1}{n}\right)=\left(\alpha_{0-, j}-\frac{1}{n}\right) \frac{\left(1+\frac{V O_{0}}{1-\tau_{C}}\right)}{\prod_{k=1}^{N-1} X_{k}+\frac{K}{\widetilde{R}} \frac{V O_{0}}{1-\tau_{C}}} \frac{1}{1-\tau_{E}}
$$

Without the debt tax shield, $V O_{0}$ and $\prod_{k=1}^{N-1} X_{k}$ take smaller numerical values and $K$ takes a larger numerical value. The effect on $K$ is independent from the length of the investment horizon, but the effects on $V O_{0}$ and $\prod_{k=1}^{N-1} X_{k}$ increase with the length of the investment horizon. That is, for longer investment horizons, these two factors gain in importance and the denominator, $\prod_{k=1}^{N-1} X_{k}+\frac{K}{\widetilde{R}} \frac{V O_{0}}{1-\tau_{C}}$, eventually increases at a faster rate than the numerator, $1+\frac{V O_{0}}{1-\tau_{C}}$. In that case, the initial equity exposure, $\alpha_{0, j}$, is smaller

\footnotetext{
${ }^{17}$ Introducing a debt tax shield results in a removal of a pure transfer of wealth without affecting the transfer of macroeconomic risk. The introduction of a debt tax shield therefore affects household investment policies differently than a reduction in the corporate tax rate.
} 
for poorer households without the debt tax shield. If, however, the remaining investment horizon is short, the numerator may grow at a faster rate than the denominator and, hence, it can happen that $\alpha_{0, j}$ is larger without the debt tax shield. Which of the two counteracting effects on the equity share dominates thus depends on the length of the remaining investment horizon as well as on the specific parameter constellation.

\subsection{Economic growth}

Our work builds on an endowment economy, in which the growth rate of the economy is by definition exogenously determined. We acknowledge that tax shields as well as the level of corporate debt could have an impact on real investments and thus the growth rate of the economy. Formulating and solving a production-economy model that explicitly investigates these effects goes beyond the scope of the present manuscript; but it is investigated in Fischer and Jensen (2019) that builds on our paper and extends it in that direction by investigating the implications of the corporate debt tax shield for the growth rate of an economy with short-lived capital.

In this section, we discuss whether the key prediction of our model that the debt tax shield affects households consumption-investment strategies should be robust to an analysis in an endowment-economy model.

In our model building on an endowment economy, the channel through which the debt tax shield affects households consumption-investment decisions is the redistributive tax system. The tax base depends on whether the debt tax shield applies. With the debt tax shield, corporate interest expenses are tax exempt, while with the debt tax shield, they are subject to taxation. Hence, the governments tax revenues depend, ceteris paribus, on whether the debt tax shield applies. Specifically, tax revenues are higher in the absence of the debt tax shield. All tax revenues are immediately redistributed equally to the households to harmonize lifetime consumption opportunities among them. Since tax revenues are higher in the absence of the debt tax shield, redistributions are also higher in the absence of the debt tax shield. That is, in the absence of the debt tax shield, our endowment-economy model predicts a higher degree of harmonization of lifetime consumption opportunities among households. Knowing that in the absence of the debt tax shield poorer households receive higher future transfer income, they consume more and save less at a younger age. 
In a growth economy, in which economic growth is determined endogenously, the channel through which the debt tax shield affects households consumption-investment decisions is the same as in our endowment economy model. In a growth economy, the tax base again depends on whether the debt tax shield applies. As in the endowment economy, the government's tax revenue thus depends on whether the debt tax shield applies or not, and tax revenues are higher in the absence of the debt tax shield. With tax revenues again being equally distributed among the households in the economy to harmonize lifetime consumption opportunities among then, redistributions are thus again higher in the absence of the debt tax shield. Consequently, also in a growth economy, a higher degree of harmonization of lifetime consumption opportunities among households should be achieved in the absence of the debt tax shield. As in an endowment economy, the poorer households know that in the absence of the debt tax shield, their future transfer income will be higher. Hence, they should also consume more and save less at a younger age in a growth economy. In other words, a production-economy model should yield the same key prediction about how the debt tax shield affects households consumption-investment decisions.

This intuition is backed up by the work of Fischer and Jensen (2019) that investigates the general equilibrium implications of the debt tax shield in a production economy. The main difference is that in a production economy setting, the interest rate as well as the dynamics of aggregate consumption become endogenous. Other key insights of our work are valid in both a production and an endowment economy setting.

Overall, our results in this section show that the debt tax shield not only affects corporate leverage and valuation, but, in general equilibrium, also households' consumption and investment decisions. Whether a households' equity and consumption share increases or decreases with the firm's leverage ratio depends on the households' initial endowment and on whether there is a tax advantage from corporate debt or not. In particular, it depends on whether the debt tax shield applies or not. In section 4, we illustrate these relationships in more detail and investigate the quantitative effects of the debt tax shield. 


\section{Quantitative effects}

In this section, we illustrate the quantitative implications of the debt tax shield on corporate leverage, the firm value, and households' consumption-investment strategies. We focus on a setting with two households, which allows us to depict our results in graphical from. Theorem 2 reveals that a household's consumption-investment strategies solely depend on its initial endowment, $\alpha_{0-, j}$, relative to that of a household with an average initial endowment, $1 / n$. In particular, a household's consumption-investment strategy is otherwise independent from the allocation of initial endowments among the other households. Hence, given the relation of a given household $j$ 's initial endowment, $\alpha_{0-, j}$, relative to that of a household with an average initial endowment, $1 / n$, the number of other households does not affect household $j$ 's consumption-investment strategy. Focusing on a setting with only two households is therefore not a restrictive assumption. We set $\alpha_{0-, 1}=0.2$, indicating that household 1 is a relatively poor household with an initial endowment of $20 \%$ of aggregate initial wealth, corresponding to $40 \%$ of the average initial endowment. ${ }^{18}$

The well-known aggregation properties of the constant relative risk aversion utility function (Merton, 1971; Rubinstein, 1974; Brennan and Kraus, 1978) imply that the setting with two households can also be interpreted as a setting with two groups of households: one group of identical relatively poor households with initial endowments below $1 / n$ and another group of relatively rich households with initial endowments above $1 / n$.

In our numerical examples, we want to illustrate both immediate and long-term consequences of corporate debt and the debt tax shield. We therefore choose an investment horizon of $N=60$ periods and assume one period corresponds to one year. We set the expected growth rate of aggregate output and its volatility to $\mu=2.0 \%$ and $\sigma=2.1 \%$, respectively, corresponding to the expected growth rate of real per capita consumption and its volatility estimated by Constantinides and Ghosh (2011). For simplicity, we focus on a setting with $M=2$ possible relations of $g$ throughout our numerical examples, implying that the two possible realizations of $g$ are $g_{1}=4.1 \%$ and $g_{2}=-0.1 \%$. ${ }^{19}$ The

\footnotetext{
${ }^{18}$ We also explored results for other levels of the poorer household's initial endowment, $\alpha_{0-, 1}$. Given that such changes do not affect our results qualitatively, we do not report them here.

${ }^{19} \mathrm{We}$ explored the robustness of our results compared to other choices of the distribution of $g$. Given
} 


\section{Figure 1}

Impact of debt tax shield on leverage and firm value
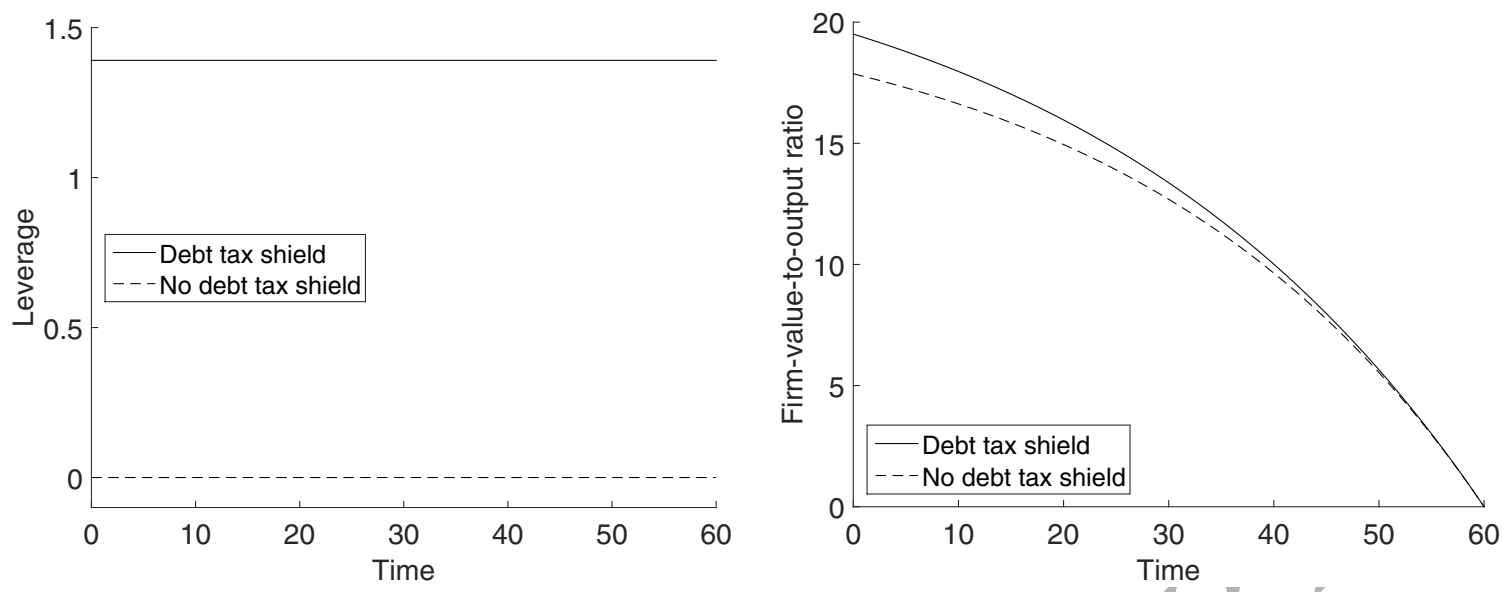

This figure depicts the impact of the debt tax shield on the firm's leverage ratio (left panel) and the firm-value-to-output ratio (right panel). The solid lines show results with the debt tax shield, the dashed lines without.

degree of risk aversion and the time-preference parameter are set to $\gamma=1$ and $\rho=0.98$, which are in the range of values typically considered in the literature. ${ }^{20}$

\subsection{Corporate valuation}

Having introduced our base-case parameter choice, we next turn to illustrating how the debt tax shield affects corporate leverage and valuation. The left panel of Figure 1 depicts how the debt tax shield affects the firm's leverage ratio, the right panel how it affects the firm's value-to-output ratio. The solid lines show results with the debt tax shield, the dashed lines without.

The tax rates in our numerical example are set to the - now historical - top tax rates for U.S. households and corporations, i.e., $\tau_{E}=20 \%, \tau_{C}=35 \%$, and $\tau_{B}=39.6 \%$. With these tax rates, the level of corporate debt is zero without the debt tax shield. With the debt tax shield, we set the degree of leverage to its exogenously imposed upper limit throughout section 4.5 to maximize the effect that the debt tax shield is allowed to have on the firm value. With the parameter constellation chosen here, this maximum possible leverage ratio is $L=1.39$. That is, matching the empirical evidence in, e.g., Givoly, Hayn, Ofer, and Sarig (1992), Graham (1996, 1999), Gordon and Lee (2001), Graham

that these changes only affect our results quantitatively, they are not reported here but are available from the authors upon request.

${ }^{20}$ We explored the robustness of our results to other levels of $\gamma$ and $\rho$. Given that such changes do not affect our results qualitatively but only quantitatively, they are not reported here. 
and Lucker (2006), Longstaff and Strebulaev (2014), Doidge and Dyck (2015), Heider and Ljungqvist (2015), Faulkender and Smith (2016), and Ljungqvist, Zhang, and Zuo (2017), the debt tax shield heavily affects the firm's optimal capital structure decision. ${ }^{21}$

The right panel of Figure 1 depicts the time-dependent but state-independent firmvalue-to-output ratio, $V O_{t}$. Confirming our results from Theorem 1, item 3, this graph shows that the firm-value-to-output ratio is lower without debt tax shield. This makes intuitive economic sense, because without the debt tax shield, a smaller share of output can be paid out to the equity holders. As a consequence, the price of equity and the firm value decrease. At time $t=0$, the firm-value-to-output ratio is $9.2 \%$ higher with the debt tax shield. That is, the debt tax shield increases the firm value by $9.2 \%$, which is in the same order of magnitude as in the empirical studies of Graham (2000), Kemsley and Nissim (2002), and vanBinsbergen, Graham, and Yang (2010). The firm-value-to-output ratio and the value of the debt tax shield decrease over the remaining investment horizon, reflecting that both the present value of future dividends and the value of the debt tax shield decrease when the remaining investment horizon shortens.

\subsection{Consumption-investment decisions}

Theoretical work on the corporate debt tax shield typically focuses on how the debt tax shield affects corporate valuation in partial equilibrium. For households' consumptioninvestment strategies, however, it should matter whether we work in partial equilibrium and (implicitly) assume that the government does not spend its tax revenues, or in general equilibrium, where tax revenues are redistributed among households. In our generalequilibrium model, tax revenues are redistributed among households in an attempt to reduce disparities in lifetime consumption opportunities among richer and poorer households. In real-world tax legislation, governments have typically implemented some redistribution mechanism from richer to poorer households, where the exact form and the share of tax revenues spent on redistributions varies between countries. ${ }^{22}$ Such redistri-

\footnotetext{
${ }^{21}$ The leverage ratio of our firm is higher than the historical leverage rates reported in Graham, Leary, and Roberts (2015), though. In our model, firms can adjust their equity and debt outstanding at no cost in any period and are otherwise void of any friction. For our numerical illustrations we have exploited the tax shield to the limit.

${ }^{22}$ In our stylized model, all tax revenues are spent on redistributions. In real-world tax legislation, this share should typically be smaller, which might quantitatively affect our results but should not alter them qualitatively.
} 


\section{Figure 2}

\section{Consumption-investment strategies in partial and general equilibrium}
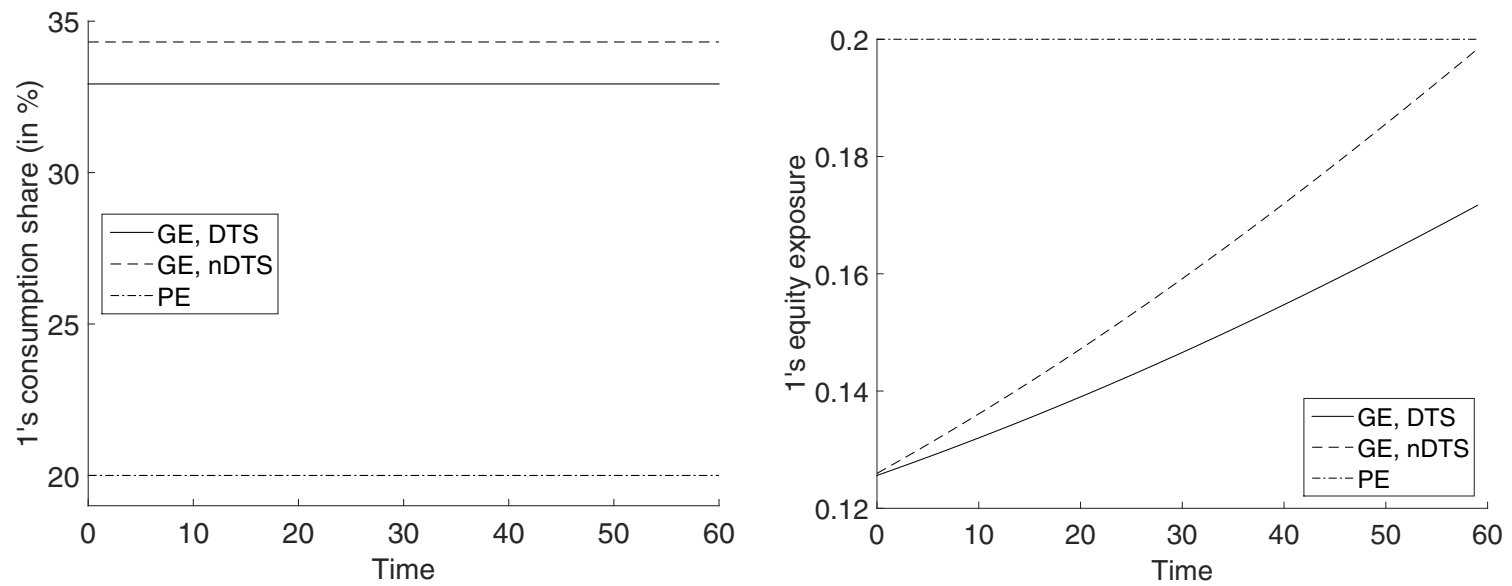

This figure depicts the impact of the debt tax shield on the poorer household 1's share of total household consumption (household 1's consumption share, left panel) and its share of equity issued (right panel) in partial and general equilibrium. The solid and the dashed lines show results in general equilibrium (GE) with the debt tax shield (DTS) and GE without (nDTS), respectively. The dash-dotted lines show results in partial equilibrium $(\mathrm{PE})$.

butions in turn directly affect households' budget constraints and should thus affect their consumption-investment strategies.

In Figure 2, we therefore compare the impact of the debt tax shield on the poorer household 1's share of total household consumption (household 1's consumption share, left panel) and its equity exposure (right panel) in partial and general equilibrium. The solid and the dashed lines show results in general equilibrium (GE) with the debt tax shield (DTS) and the GE without (nDTS), respectively. The dash-dotted lines show results in partial equilibrium (PE), where the poorer household 1's share of total household consumption and its equity exposure are independent of whether the debt tax shield applies or not.

Both graphs in Figure 2 show that households' consumption-investment strategies are heavily affected by whether a partial or a general-equilibrium model is applied. In general equilibrium, the poorer household 1's consumption share is significantly higher than in partial equilibrium and the equity share lower, stressing that government policy has a first-order effect on household behavior.

In general equilibrium, the poorer household 1's consumption share and equity exposure are affected by whether the debt tax shield applies or not. In partial equilibrium, 
results are independent of whether the debt tax shield applies or not, reflecting the absence of transfer income. Without transfer income, there is no transfer of macroeconomic risk and households do not trade with each other. Hence, their consumption shares and equity exposures correspond to their initial endowments, irrespective of whether the debt tax shield applies or not.

In general equilibrium, the poorer household 1's consumption share is higher without the debt tax shield, because the absence of the debt tax shield implies higher tax revenues and thus larger transfers from richer to poorer households. In contrast to, e.g., a higher tax rate on corporate gains, the removal of the debt tax shield solely results in an increased transfer of wealth but not in an additional transfer of macroeconomic risk. This additional wealth transfer implies an increase in the poorer household 1's consumption share by about 1.4 percentage points. The partial equilibrium approach, however, predicts the consumption share to be independent of whether the debt tax shield applies or not.

The right panel of Figure 2 shows that not only the poorer household 1's consumption share, but also its equity exposure, is heavily affected by whether we work in partial or general equilibrium. In general equilibrium, the poorer household 1's equity holdings are lower than the households' initial endowment and are increasing over the investment horizon, whereas in partial equilibrium, the poorer household's demand for equity is constant and independent of whether the debt tax shield applies or not. These results are driven through three channels.

First, from the left panel of Figure 2 and Theorem 2, item 3, we know that in general equilibrium, poorer households' consumption shares are higher than their initial endowments. To finance a consumption share exceeding the initial endowment, the poorer household 1 thus has to dissave, in turn suggesting a decrease in the optimal equity exposure. The extent to which household 1 dissaves is higher without the debt tax shield, reflecting that the higher future transfer income allows the poorer household 1 to finance a higher consumption share over the entire investment horizon. In other words, future transfer income causes a second effect, namely a positive wealth effect for poorer households that is not accounted for in official statistics. Instead, this wealth effect represents the present value of future transfers. This wealth effect suggests an increase in the optimal equity exposure. 
The order of magnitude of this wealth effect decreases over time. Consequently, the poorer household 1 has to increase its savings over the life cycle to remain able to finance the desired consumption share. Given that the poorer household 1's consumption share is higher without the debt tax shield, household 1 has to build up more wealth in that setting. With increasing household savings, the optimal equity exposure is affected through a third channel. To account for the implied decrease in imputed macroeconomic risk, the household increases its exposure to equity.

In partial equilibrium, there are no government transfers and, hence, there is no wealth effect from them. Likewise, households are not subject to imputed macroeconomic risk from the redistribution mechanism. That is, in partial equilibrium they are not subject to the second and the third effect. Consequently, the linear risk-sharing motive implies a constant equity share.

Overall, our results in this section show that a general equilibrium approach is necessary for a better understanding of the implications of the debt tax shield for households' consumption-investment policies. In fact, partial equilibrium leads to very different predictions about how the debt tax shield affects household behavior. As a result, we focus on the general-equilibrium model throughout and next turn to illustrating how the level of the corporate tax rate affects our results.

For corporate tax rates below $24.5 \%$, there is a tax advantage to using equity irrespective of whether the debt tax shield applies or not. Hence, for such levels of the corporate tax rate, the firm operates without corporate leverage (upper left panel of Figure 3). For levels of the corporate tax rate exceeding $24.5 \%$, it remains optimal to operate without leverage when no debt tax shield applies. With the debt tax shield, however, there is now a tax advantage to debt financing and the firm operates with the maximum possible level of corporate leverage that fulfills Equation (17) and guarantees a non-negative dividend.

\subsection{Impact of corporate tax rate}

In this section, we illustrate the general-equilibrium impact of the corporate tax rate. For that purpose, we vary this tax rate between $\tau_{C}=0 \%$ and $\tau_{C}=90 \%$. In Figure 3 , we illustrate how the corporate tax rate affects the firm's leverage ratio (upper left panel), the firm-value-to-output ratio at time $t=0$ (upper right panel), household 1's consumption share (lower left panel), and its exposure to equity at time $t=0$ (lower right 
panel). The solid lines show results with the debt tax shield, the dashed lines without.

\section{Figure 3}

\section{Impact of corporate tax rate}
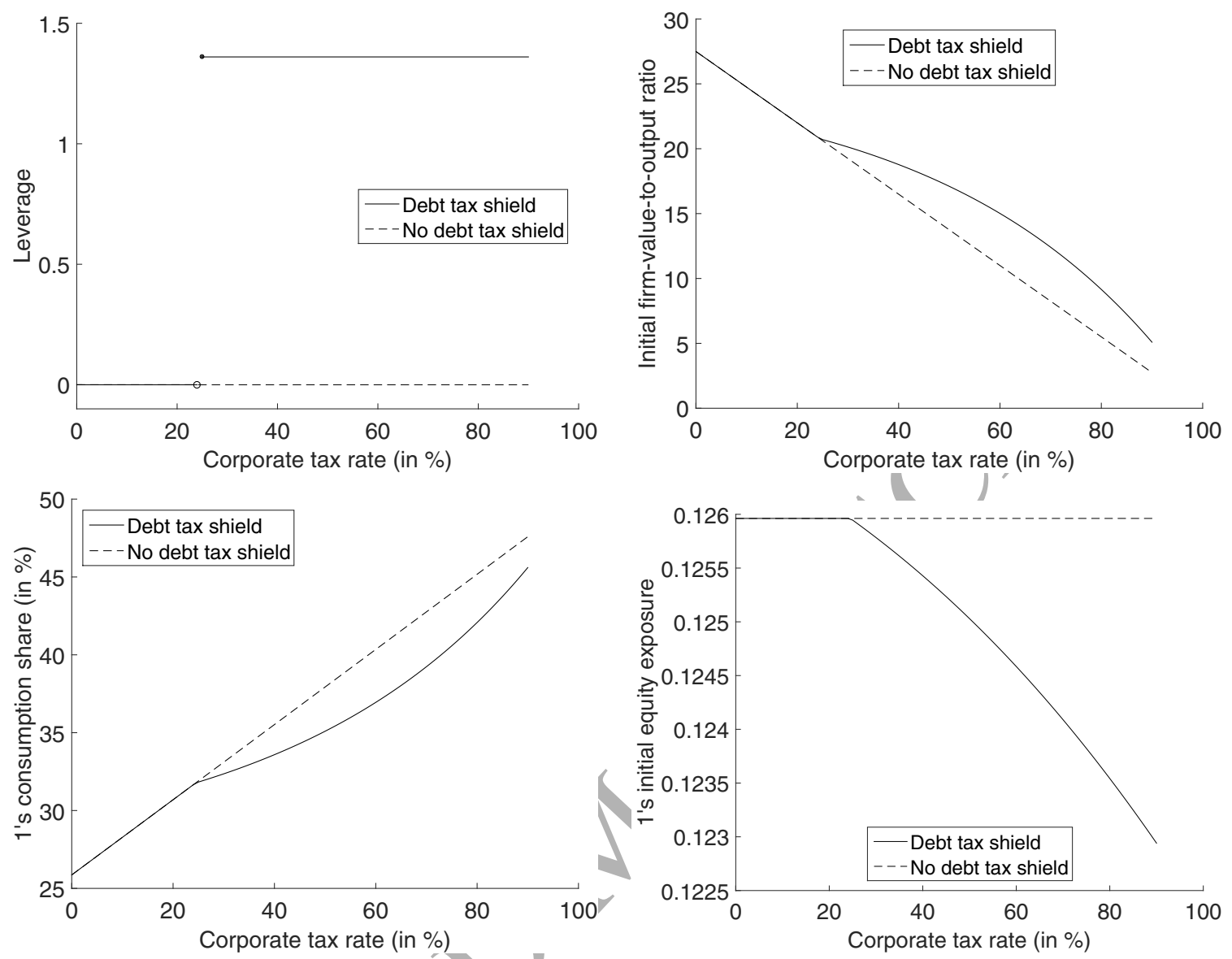

This figure depicts the impact of the corporate tax rate on the firm's leverage ratio (upper left panel), the firm-value-to-output ratio at time $t=0$ (upper right panel), the poorer household 1's consumption share (lower left panel), and its equity exposure at time $t=0$ (lower right panel). The solid lines show results with the debt tax shield, the dashed lines without.

The upper right panel of Figure 3 shows how the level of the corporate tax rate affects corporate valuation at time $t=0$. For levels of the corporate tax rate below $24.5 \%$, results are identical/rrespective of whether the debt tax shield applies or not, because the firm operates without leverage in both cases. In that region, the firm-value-to-output ratio decreases linearly in the level of the corporate tax rate, reflecting that the share of output going to the shareholders decreases linearly with the corporate tax rate. For levels of the corporate tax rate exceeding $24.5 \%$, this relationship remains valid without the debt tax shield where the firm continues to operate without leverage.

With the debt tax shield, the firm operates with leverage and corporate valuation is 
affected through two counteracting channels. First, the share of corporate profits falling to shareholders decreases, suggesting a decrease in the firm-value-to-output ratio with increasing corporate tax rate. Second, the tax advantage to corporate debt points to an increase in corporate valuation that increases in the level of the corporate tax rate, because the value of the debt tax shield increases in the corporate tax rate. This second effect results in a higher firm-value-to-output ratio when the debt tax shield applies.

The lower left panel of Figure 3 shows how the level of the corporate tax rate affects the poorer household 1's consumption share. For levels of the corporate tax rate below $24.5 \%$, results are independent of whether the debt tax shield applies or not, because the firm operates without leverage in both cases. In that region, the poorer household 1's consumption share increases linearly in the level of the corporate tax rate, causing a direct effect through the increasing transfers. For levels of the corporate tax rate exceeding $24.5 \%$, the poorer household 1's consumption share continues to increase linearly in the corporate tax rate when the debt tax shield does not apply, because, in that case, the firm continues to operate without leverage.

When the debt tax shield applies, however, the firm operates with leverage for corporate tax rates exceeding $24.5 \%$. In addition to the level of transfers generally increasing in the level of the corporate tax rate, a counteracting second indirect effect influences household 1's consumption share. Once the firm operates with leverage, it reduces its taxable profits, the tax basis for the corporate tax rate. In other words, leverage reduces corporate tax revenues and thus transfers. Hence, the poorer household 1's consumption share should increase at a slower rate than without the debt tax shield.

The lower right graph in Figure 3 shows how the level of the corporate tax rate affects the poorer household 1's equity exposure at time $t=0$. The bottom line result is that the level of the corporate tax rate only has a weak effect on households 1's equity exposure. From Equation (35), asymptotically, the equity share is independent from the corporate tax rate, reflecting that the implied increased wealth transfer and transfer of macroeconomic risk offset each other exactly. With an investment horizon of $T=60$ periods, we still observe a weak decrease in households 1's equity exposure when the debt tax shield applies, indicating a faster rate of convergence when the debt tax shield does not apply. 


\subsection{Impact of risk aversion}

In this section, we ask how the degree of risk aversion, $\gamma$, affects optimal consumption and investment decisions. Intuitively, optimal consumption and investment strategies should be affected by the degree of risk aversion through two counteracting channels. On the one hand, optimal consumption-investment strategies should be affected by the elasticity of intertemporal substitution (EIS). In our model with CRRA preferences, the degree of risk aversion, $\gamma$, simultaneously determines the EIS, $1 / \gamma$. Hence, an increase in the degree of risk aversion implies a decrease of the EIS. Low level of the EIS indicate a strong willingness among the households to achive a smooth consumption stream. In our endowment economy in which the households agree upon constant consumption shares, attaining such a constant consumption share should be most expensive (in terms of the consumption level attained) for that household whose consumption share prior to trading is particularly volatile, i.e., for the poorer household who receives volatile transfer income. In other words, with decreasing EIS, the poorer households have to pay more in terms of the level of their attainable consumption to attain a constant consumption share. For this EIS-channel, an increase in risk aversion should lead to a lower consumption share for the poorer household.

On the other hand, an increase in risk aversion leads to lower expected returns on the assets and thus to lower expected redistributions. These effects should be particularly important in the absence of the debt tax shield, where redistributions are higher. From this redistribution channel, an increase in risk aversion should lead to a higher consumption share for the poorer households. In Figure 4 we investigate whether one of these two channels systematically dominates and further ask how the poorer household 1's equity share is affected by risk aversion.

From the left panel of Figure 4, the poorer household 1's consumption share increases in the degree of risk aversion for lower levels of risk aversion, indicating that the effects from the redistribution channel outweigh the effects from the EIS channel. For higher degrees of risk aversion, however, the poorer household 1's consumption share decreases in risk aversion, indicating that for these levels of risk aversion, the EIS channel outweighs the redistribution channel. Without the debt tax shield, the redistribution channel is first outweighed by the EIS channel at a higher level of risk aversion, reflecting that 
Figure 4

Impact of risk aversion

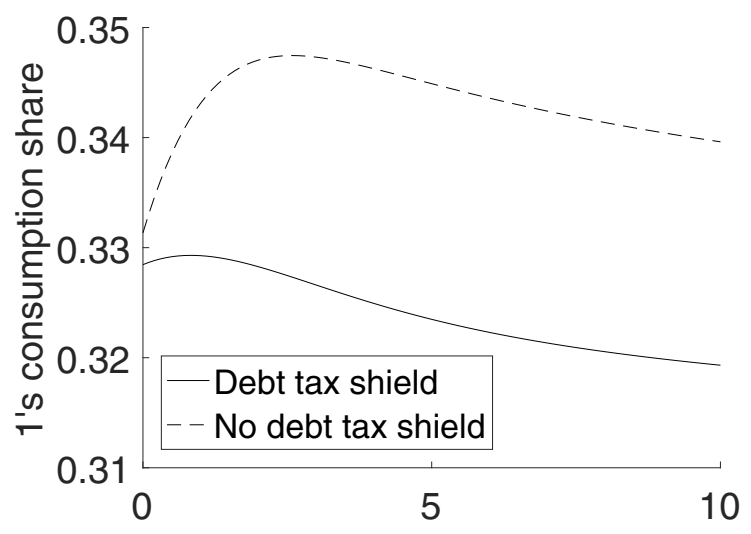

Risk aversion

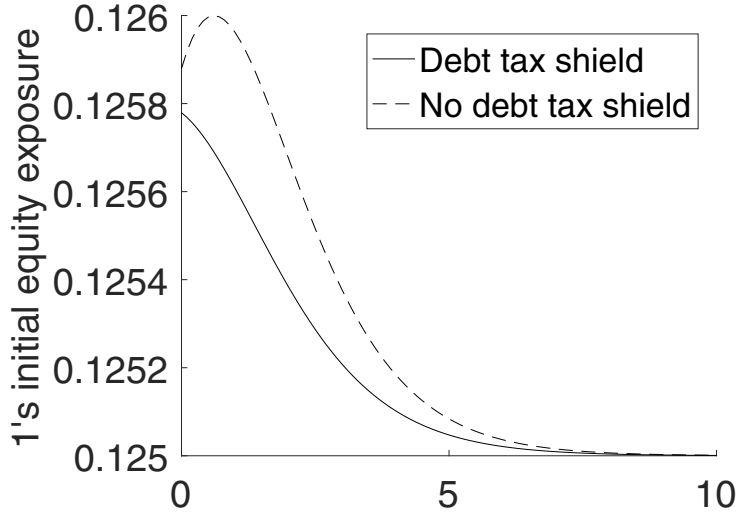

Risk aversion

This figure depicts the impact of risk aversion on the poorer households 1's consumption share (left panel) and its equity exposure at time $t=0$ (right panel). The solid lines show results with the debt tax shield, the dashed lines without.

redistributions are generally higher in the absence of the debt tax shield.

The left panel of Figure 4 further shows that the gap between consumption share in settings with and without debt tax shield widens with the degree of risk aversion particularly for low initial levels of risk aversion. This result reflects that the maximum degree of corporate leverage increases in the degree of risk aversion, cf. Equations (17) and (18). Hence, the amount of transfer income that is not subject to macroeconomic risk is lower, thus substantially weakening the EIS channel. As a consequence of the weakened EIS channel, the consumption share increases.

From the right panel of Figure 4, the poorer household 1's optimal equity share is only affected very little by the degree of risk aversion, reflecting that in our general equilibrium endowment economy model with an exogenously given supply of the risky asset, the primary role of this asset is to ensure a consumption-smoothing policy that enables the households to attain constant consumption shares.

\subsection{Equivalent tax rates}

Having depicted how the debt tax shield affects corporate valuation and households' consumption and investment strategies, we next ask by how much tax rates could be reduced, provided the government removes an existing debt tax shield and poorer households are required to attain the same levels of welfare as before the removal of the debt 
Figure 5

Reductions in tax rates from removing a debt tax shield

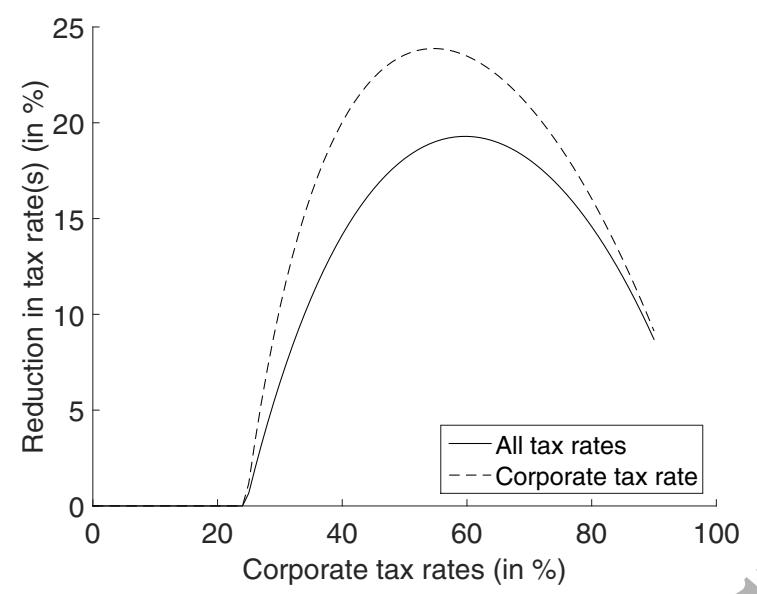

This figure shows by how much tax rates can be reduced when an existing debt tax shield is removed and all households must attain the same levels of welfare as before the removal. The solid line shows by which common rate all tax rates can be reduced, the dashed line by which rate the corporate tax rate, $\tau_{C}$, can be reduced, if all other tax rates are held constant.

tax shield. ${ }^{23}$ To quantify these reductions in tax rates, we ask two questions:

1. How much can the corporate tax rate, $\tau_{C}$, be reduced when keeping the tax rates on equity income, $\tau_{E}$, and on interest income on household level, $\tau_{B}$, constant?

2. How much can all three of these tax rates be reduced simultaneously?

From a more technical perspective, we change the way of analyzing the implications of the debt tax shield in this section. Whereas we have so far asked how the debt tax shield, cet. par., affects corporate leverage as well as households' optimal consumption-investment decisions, we now take a different perspective and ask how much tax rates can be reduced after the removal of an existing debt tax shield to attain the same level of welfare for all households as before the removal of the debt tax shield.

Figure 5 depicts by how much tax rates can be reduced when an existing debt tax shield is removed in order for the poorer households' welfare levels to remain unaffected. The solid line shows by which common rate all tax rates can be reduced, the dashed line shows by which rate the corporate tax rate, $\tau_{C}$, can be reduced, if all other tax rates

\footnotetext{
${ }^{23}$ When poorer households attain the same welfare levels, they also attain the same consumption shares. Hence, richer households' consumption shares are not altered either, and they also attain the same welfare levels.
} 
are held constant. For corporate tax rates below 24.5\%, the firm does not operate with leverage. Hence, the removal of an existing debt tax shield does not have an impact on households' welfare, and tax rates thus cannot be reduced when an existing debt tax shield is removed.

For tax rates exceeding $24.5 \%$, the firm levers up to benefit from the debt tax shield. In that case, the debt tax shield reduces the government's tax revenues and the government can generate the same amount of tax revenues with lower tax rates.

Welfare-preserving reductions in tax rates are driven by two opposing effects. First, reductions in the government's tax revenues resulting from the debt tax shield are higher, the higher the corporate tax rate is. This effect suggests that possible reductions in tax rates increase in the level of the corporate tax rate. Second, along, with the corporate tax rate, the government's tax revenues and redistributions increase. That is, with an increasing corporate tax rate, an increasing share of output is redistributed, suggesting that possible reductions in tax rates decrease in the level of the corporate tax rate especially when the initial level of the corporate tax rate is already high.

Our results in Figure 5 show that for realistic levels of the corporate tax rate exceeding $24.5 \%$, reductions in tax rates increase in the level of the corporate tax rate. That is, the first effect outweighs the second. For instance, with a corporate tax rate of $35 \%$, a removal of an existing debt tax shield allows for a reduction in the corporate tax rate by $15 \%$, i.e., a reduction to $\tau_{C}=29 \%$. Alternatively, the removal of the debt tax shield allows a decrease in all tax rates by $11 \%$. These values increase to reductions of $24 \%$ and $18 \%$, respectively, when the corporate tax rate is $50 \%$. For very high levels of the corporate tax rate, reductions in tax rates decrease in the level of the corporate tax rate, indicating that the second effect outweighs the first.

\subsection{Impact of corporate leverage}

In this section, we abandon the assumption of an endogenous determination of corporate leverage subject to the solvency constraint from Equation (17) and instead ask how different levels of corporate leverage affects our results. Further restrictions on the degree of leverage may reflect financial frictions such as borrowing constraints. In Figure 6 , we illustrate how the firm's leverage ratio affects the firm-value-to-output ratio at time $t=0$ (left panel) and household 1's consumption share (right panel). The solid lines 
Figure 6

Impact of corporate leverage
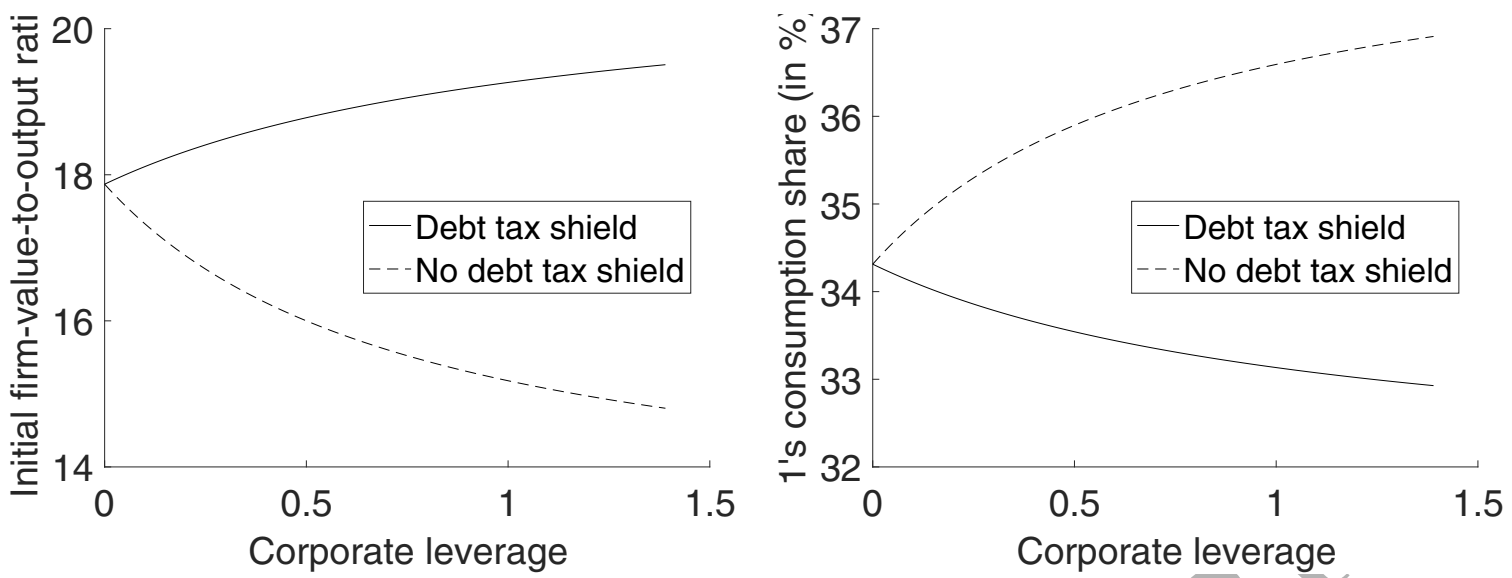

This figure depicts the impact of corporate leverage on the firm-value-to-output ratio at time $t=0$ (left panel) and the poorer household 1's consumption share (right panel). The solid lines show results with the debt tax shield, the dashed lines without.

show results with the debt tax shield, the dashed lines without.

The results in the left panel show that the firm-value-to-output ratio at time $t=0$ increases in the leverage ratio with the debt tax shield and decreases without. The relationship between corporate leverage and the firm-value-to-output ratio is nonlinear, because an increase in the leverage ratio does not only imply an increase in corporate debt, but simultaneously a decrease in firm equity.

With the debt tax shield, there is a tax advantage from using debt if $1-\tau_{B}>$ $\left(1-\tau_{E}\right)\left(1-\tau_{c}\right)$. With our parameter choice, it holds that $\left(1-\tau_{B}\right)=60.4 \%>52 \%=$ $\left(1-\tau_{E}\right)\left(1-\tau_{c}\right)$. Hence, there is a tax advantage from using corporate debt, and corporate leverage has a positive impact on the firm value. The firm-value-to-output ratio therefore increases as leverage does. Without the debt tax shield, there is a tax advantage of using equity: $1-\tau_{E}=80 \%>60.4 \%=1-\tau_{B}$. Without the debt tax shield, corporate leverage thus has a negative impact on the firm value and the firm-value-to-output ratio decreases as the leverage ratio increases.

Without the debt tax shield, the total tax burden on bonds is higher than on equity. Consequently, tax revenues and thereby redistribution increases in the level of corporate debt. The poorer household 1's consumption share is therefore higher, the more corporate debt the firm is operating with. With the debt tax shield, however, the total tax burden on bonds is lower than that on equity. Hence, tax revenues and thereby redistributions 
decrease in the level of corporate debt. Therefore, the poorer household's consumption share decreases as corporate leverage increases.

\section{Conclusion}

This paper contributes to a growing strand of literature investigating the implications of the debt tax shield by exploring its general-equilibrium implications for household behavior in a Lucas tree economy with a redistributive tax system that taxes household income and firm profits and redistributes tax revenues in such a way that relatively rich households are net contributors to poorer ones.

Whereas the implications of the debt tax shield for corporate leverage and valuation are well-understood in partial equilibrium, understanding how the debt tax shield affects households' consumption and investment decisions requires a general-equilibrium framework. In this paper, we confirm that consistent with what has been documented in partial equilibrium, the debt tax shield also increases corporate valuation in general equilibrium. However, partial and general-equilibrium approaches lead to opposite predictions about how the debt tax shield affects poorer households' consumption shares of aggregate production. Our partial equilibrium approach predicts consumption shares to be constant and independent of the existence of a debt tax shield, whereas the general-equilibrium model shows that poorer households' consumption shares in fact are higher in the absence of a debt tax shield.

The channel through which poorer households' consumption shares are affected is the redistributive tax system. Without the debt tax shield, the basis for taxation on the corporate level is higher for a levered firm, leading to higher tax revenues and lower returns on investing into firm equity. In general equilibrium, tax revenues are redistributed among households, and poorer households receive more in transfers than they pay in taxes, thus enabling them to consume a share of aggregate output exceeding their share of the aggregate initial endowment.

To finance higher consumption shares, poorer households dissave at the beginning of the investment horizon. Yet, to finance the higher consumption shares towards the end of the investment horizon, they have to build up savings, which they do with the help of their transfer income. These effects are stronger when no debt tax shield applies, because 
consumption shares are more affected in that case. As a consequence, when no debt tax shield applies, equity shares vary more over time. Poorer households' equity shares are lower towards the beginning of the investment horizon and higher at the end of the investment horizon.

In the absence of a debt tax shield, our model predicts that the government can attain the same allocation of consumption shares and welfare among households with significantly lower tax rates than in the presence of a debt tax shield. For example, with tax rates of $20 \%$ on capital gains and dividends, $35 \%$ on corporate profits, and $39.6 \%$ on interest income on the household level, the tax rate on corporate profits could be reduced from $35 \%$ to $29 \%$ when removing an existing debt tax shield without altering poorer households' welfare levels. Overall, this paper shows that, in addition to the welldocumented impact of the debt tax shield on corporate valuation, the debt tax shield also heavily affects household consumption and investments.

Our work can be extended in multiple directions. For example, it would be interesting to investigate how heterogeneity in households preferences affects corporate valuation with and without the debt tax shield. It/would further be interesting to consider how progressive taxation affects our results. We leave these interesting issues for further research. In our endowment economy model, the growth rate of the economy is exogenously determined. In future work, it would be interesting to allow for an endogenous determination of economic growth to assess whether the debt tax shield has a positive impact on economic growth. This issue is investigated in more detail in the work of Fischer and Jensen (2019).

\section{Acknowledgements}

We are grateful for helpful comments and suggestions from Ansgar Belke, Harjoat Bhamra, Kay Blaufus, Martin Brown, John Duca, Yauheniya Filipyeva, Patrick Grüning, Frederik Lundtofte, Jost Heckemeyer, Bertrand Koebel, Angelo Ranaldo, Lukas Schmid, Paul Söderlind, Ngoc-Khanh Tran, Stefan Wielenberg and seminar participants at Leibniz University Hannover, University of Sankt Gallen, University of Strasbourg, the Arne Ryde Workshop in Financial Economics at Lund University, the Midwest Finance Association Meeting in Atlanta, the SGF Meeting in Zürich, and the World Finance Meeting in 


\section{Cagliari.}

\section{References}

Alesina, A., Angeletos, G.-M., 2005. Fairness and redistribution. American Economic Review 95 (4), 960-980.

Alvaredo, F., Atkinson, A. B., Piketty, T., Saez, E., 2013. The top 1 percent in international and historical perspective. Journal of Economic Perspectives 27 (3), 3-20.

Atkinson, A. B., Piketty, T., Saez, E., 2011. Top incomes in the long run of history. Journal of Economic Literature 49 (1), 3-71.

Barro, R., 1974. Are government bonds net wealth? Journal of Political Economy 82 (6), 1095-1117.

Becker, B., Jacob, M., Jacob, M., 2013. Payout taxes and the allocation of investment. Journal of Financial Economics 107 (1), 1-24.

Bell, L., Jenkinson, T., 2002. New evidence of the impact of dividend taxation and on the identity of the marginal investor. Journal of Finance 57 (3), 1321-1346.

Berk, J., DeMarzo, P., 2013. Corporate Finance, 3rd Edition. Pearson, Addison Wesley.

Brennan, M. J., Kraus, A., 1978. Necessary conditions for aggregation in securities. Journal of Financial and Quantitative Analysis 13 (3), 407-418.

Christensen, P. O., Feltham, G. A., 2009. Equity valuation. Foundations and Trends in Accounting 4 (1), $1-112$.

Constantinides, G. M., Ghosh, A., 2011. Asset pricing tests with long-run risks in consumption growth. Review of Asset Pricing Studies 1 (1), 96-136.

Cooper, I. A., Nyborg, K. G., 2006. The value of tax shields is equal to the present value of tax shields. Journal of Financial Economics 81 (1), 215-225.

Cooper, I. A., Nyborg, K. G., 2008. Tax-adjusted discount rates with investor taxes and risky debt. Financial Management 37 (2), 365-379.

de Mooij, R. A., Devereux, M. P., 2011. An applied analysis of ace and cbit reforms in the eu. International Tax and Public Finance 18 (1), 93-120.

DeAngelo, H., Roll, R, 2015. How stable are corporate capital structures? Journal of Finance 70 (1), $373-418$.

Devereux, M. P., Maffini, G., Xing, J., 2015. Corporate tax incentives and capital structure: empirical evidence from UK tax returns, Oxford University.

Doidge, C., Dyck, A., 2015. Taxes and corporate policies: evidence from a quasi natural experiment. Journal of Finance 70 (1), 45-89.

European Commission, 2016. Council Directive (EU) 2016/1164. (ATA directive), 12 July 2016.

Faccio, M., Xu, J., 2015. Taxes and capital structure. Journal of Financial and Quantitative Analysis $50(3), 1-24$.

Fama, E. F., 2011. My life in finance. Annual Review of Financial Economics 3 (1), 1-15. 
Fan, J. P., Titman, S., Twite, G., 2012. An international comparison of capital structure and debt maturity choices. Journal of Financial and Quantitative Analysis 47 (1), 23-56.

Fatica, S., Hemmelgarn, T., Nicodeme, G., 2013. The debt-equity tax bias: Consequences ands solutions. Reflets Perspectives de la vie conomique 52 (1), 5-18.

Faulkender, M., Smith, J., 2016. Taxes and leverage at multinational corporations. Journal of Financial Economics $122(1), 1-20$.

Fischer, M., Jensen, B. A., 2015. Taxation, transfer income and stock market participation. Review of Finance 19 (2), 823-863.

Fischer, M., Jensen, B. A., 2019. The debt tax shield, economic growth and inequality, Copenhagen Business School.

Giesecke, K., Goldberg, L. R., 2004. In search of a Modigliani-Miller economy. Journal of Investment Management 2 (3), 45-50.

Givoly, D., Hayn, C., Ofer, A. R., Sarig, O., 1992. Taxes and capital structure; Evidence from firms' response to the tax reform act of 1986. Review of Financial Studies 5 (2), 331-355.

Glover, B., Gomes, J. F., Yaron, A., 2015. Corporate taxes, leverage, and business cycles, Tepper School of Business.

Gordon, M. J., 1959. Dividend earnings and stock prices. Review of Economics and Statistics 41 (2), 99-105.

Gordon, M. J., Shapiro, E., 1956. Capital equipment analysis: the required rate of profit. Management Science 3 (1), 102-110.

Gordon, R. H., Lee, Y., 2001. Do taxes affect corporate debt policy? Evidence from U.S. corporate tax return data. Journal of Public Economics 82 (2), 195-224.

Graham, J. R., 1996. Debt and the marginal tax rate. Journal of Financial Economics 41 (1), 41-73.

Graham, J. R., 1999. Do personal taxes affect corporate financing decisions? Journal of Public Economics $73(2), 147-185$.

Graham, J. R., 2000. How big are the tax benefits of debt? Journal of Finance 55 (5), 1901-1941.

Graham, J. R., Leary, M. T., Roberts, M. R., 2015. A century of capital structure: The leveraging of corporate america. Journal of Financial Economics 118 (3), 658-683.

Graham, J, R., Lucker, A. L., 2006. Tax shelters and corporate debt policy. Journal of Financial Economics $81(3), 563-594$.

Grant, C., Koulovatianos, C., Michaelides, A., Padula, M., 2010. Evidence on the insurance effect of redistributive taxation. Review of Economics and Statistics 92 (4), 965-973.

Halling, M., Yu, J., Zechner, J., 2016. Leverage dynamics over the business cycle. Journal of Financial Economics $122(1), 21-41$.

Heider, F., Ljungqvist, A., 2015. As certain as debt and taxes: Estimating the tax sensitivity of leverage from state tax changes. Journal of Financial Economics 118 (3), 684-712.

Hovakimian, A., Opler, T., Sheridan, T., 2001. The debt-equity choice. Journal of Financial and Quantitative Analysis 36 (1), 1-24. 
Kemsley, D., Nissim, D., 2002. Valuation of the debt tax shield. Journal of Finance 57 (5), 2045-2073.

Korajczyk, R., Levy, A., 2003. Capital structure choice: Macroeconomic conditions and financial constraints. Journal of Financial Economics 68 (1), 75-109.

Ljungqvist, A., Zhang, L., Zuo, L., 2017. Sharing risk with the government: on the causal effects of taxes on corporate risk-taking. Journal of Accounting Research 55 (3), 669-707.

Longstaff, F. A., Strebulaev, I. A., 2014. Corporate taxes and capital structure: A long-term historical perspective, NBER Working Paper No. 20372.

Lucas, R. E., 1978. Asset prices in an exchange economy. Econometrica 46 (6), 1429-1445.

MacKie-Mason, J., 1990. Do taxes affect corporate financing decisions? Journal of Finance 45 (5), $1471-1493$.

Meltzer, A. H., Richard, S. F., 1981. A rational theory of the size of government. Journal of Politial Economy 89 (5), 914-927.

Merton, R. C., 1971. Optimal consumption and portfolio rules in a continuous-time model. Journal of Economic Theory 3 (4), 373-413.

Miles, J. A., Ezzell, J. R., 1980. The weighted average cost of capital, perfect capital markets and project life: A clarification. Journal of Financial and Quantitative,Analysis 15 (3), 719-730.

Miller, M. H., 1977. Debt and taxes. Journal of Finance 32 (2), 261-275.

Modigliani, F., Miller, M. H., 1958. The cost of capital, corporation finance and the theory of investment. American Economic Review 48 (3), 261-297.

Öztekin, Ö., 2015. Capital structure decisions around the world: Which factors are realiably important? Journal of Financial and Quantitative Analysis 50 (3), 301-323.

Pástor, L., Veronesi, P., 2016. Income inequality and asset prices under redistributive taxation. Journal of Monetary Economics 81 (1), 1-20.

Pástor, L., Veronesi, P., 2017. Political cycles and stock returns, NBER Working Paper No. 23184.

Piketty, T., 2014. Capital in the 21st Century. Harvard University Press, Cambridge.

Piketty, T., Saez, E., 2003. Income inequality in the united states, 1913-1998. Quarterly Journal of Economics $118(1), 1-39$.

Romer, T., 1975. Individual welfare, majority voting, and the properties of a linear income tax. Journal of Public Economics 4 (2), 163-185.

Rubinstein, M., 1974. An aggregation theorem for securities markets. Journal of Financial Economics $1(3), 225=244$.

Rubinstein, M., 1976. The valuation of uncertain income streams and the pricing of options. Bell Journal of Economics 7 (2), 407-425.

Rubinstein, M., 2003. Great moments in financial economics: II. Modigliani-Miller theorem. Journal of Investment Management 1 (2), 7-13.

Schepens, G., 2016. Taxes and bank capital structure. Journal of Financial Economics 120 (3), 585-600.

Sialm, C., 2006. Stochastic taxation and asset pricing in dynamic general equilibrium. Journal of Economic Dynamics and Control $30(3), 511-540$. 
Spengel, C., Schmidt, F., Heckemeyer, J., Nicolay, K., 2016. The effects of tax reforms to address the debt-equity bias on the cost of capital and on effective tax rates. European commission taxation papers no. 65, Centre for Euroepan Economic Research (ZEW) GmbH.

vanBinsbergen, J. H., Graham, J. R., Yang, J., 2010. The cost of debt. Journal of Finance 65 (6), 2089-2136.

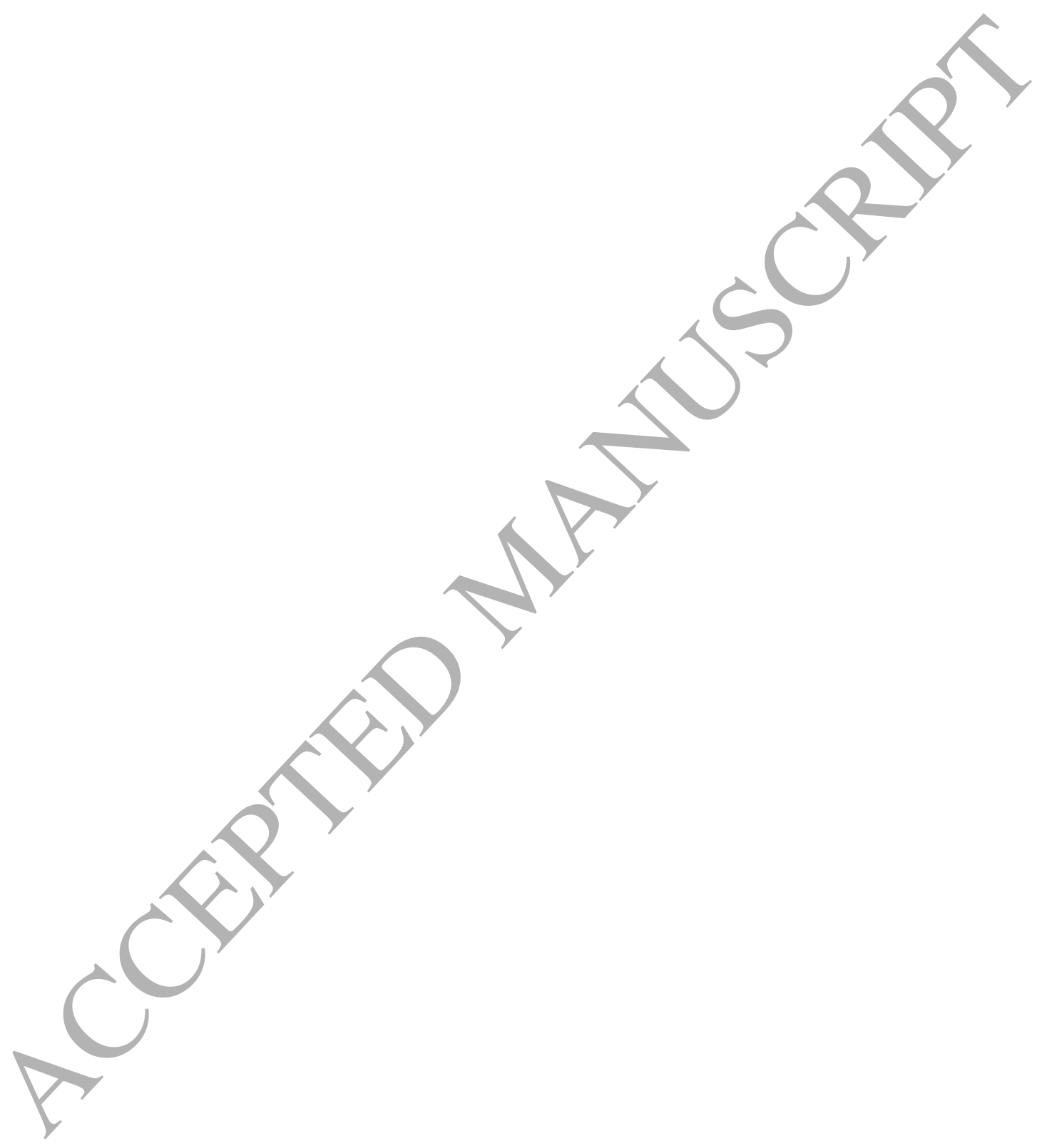

